\title{
Recruitment Niches of Enterolobium contortisiliquum (Vell.) Morong: Functional Acclimations to Light
}

\author{
Vicente Luiz Naves ${ }^{1}$ * (D) , Serge Rambal ${ }^{2}$ (D) , João Paulo R. A. D. Barbosa ${ }^{3}$, \\ Evaristo Mauro de Castro ${ }^{3}$ and Moacir Pasqual ${ }^{4}$ \\ 1 Department of Biology, University of Lavras (UFLA), Lavras 37200-000, Brazil \\ 2 Centre d'Ecologie Fonctionnelle Evolutive (CEFE), 34293 Montpellier, France; serge.rambal@cefe.cnrs.fr \\ 3 Department of Biology, UFLA, Lavras 37200-000, Brazil; jp.barbosa@dbi.ufla.br (J.P.R.A.D.B.); \\ emcastro@gmail.com (E.M.d.C.) \\ 4 Department of Agriculture, UFLA, Lavras 37200-000, Brazil; mpasqual@dag.ufla.br \\ * Correspondence: naves.agro@hotmail.com; Tel.: +55-35-98800-5957
}

Received: 17 January 2018; Accepted: 30 April 2018; Published: 13 May 2018

\begin{abstract}
Adjustments that a tree species displays in acclimating to light conditions may explain its fate in different forest successional stages. Enterolobium contortisiliquum (Vell.) Morong is a tree found in contrasting light environments and used in reforestation programs because of its rapid growth. This study analyzed the performance of tamboril seedlings grown in three light environments: FS - full sun ( $100 \%$ of photosynthetically active radiation (PAR) and a red/far-red ratio (R/FR) of 1.66), S-shade net (38\% of PAR and a R/FR of 1.54) and I-Insulfilm ${ }^{\circledR}$ (Insulfilm, São Paulo, Brazil) shade cloth (24\% of PAR and a R/FR of 0.69$)$. Greater net assimilation, higher root/shoot ratio, higher stomatal density, and reduced leaf area are some of the functional traits developed by tamboril to acclimate to full sun. On the other hand, a larger leaf area associated with a greater specific leaf area, higher leaf area ratio, higher leaf number and leafing intensity, as well as higher chlorophyll and carotenoid contents are among the most important traits for tamboril to acclimate to shade. The seedlings growing in FS displayed the best quality index. However, the traits developed in the nursery under each light condition could promote the successful installation and survival of tamboril seedlings under similar conditions in the field.
\end{abstract}

Keywords: photosynthetic acclimation; leaf plasticity; shade tolerance; shade avoidance; seedling production

\section{Introduction}

Helping recover a degraded forest ecosystem by introducing either endemic or exotic trees is an activity that requires knowledge of those species' ecology and particularly their interactions with abiotic factors such as light availability, quality, and duration [1]. The knowledge of functional processes for tropical forest species, especially responses to light, is important to preserve plants with high economic potential and is also crucial to guide the production of suitable seedlings for reforestation programs [2-4]. The natural- and/or human-induced gaps occurring in a forest are vital sites for the internal regeneration and management of tropical forests. In addition, the differences in light quantity and quality in gaps and understory locations have direct effects on seed germination, seedling growth, and fitness $[5,6]$.

Understanding the way plants adjust morphologically and physiologically to varying light conditions can be helpful to explain their occurrence and distribution $[1,7,8]$. For instance, in deforested areas in the Amazonian region, early successional or pioneer species show greater tolerance to new environmental conditions due to a high level of tolerance to high irradiance. On the other hand, compared to late 
successional or so-called climax species, mortality rates are high, growth is affected, and reforestation of those degraded areas with late successional species is usually unsuccessful [9]. The differential ability of a species to cope with light, particularly during the establishment stage, is considered a key trait governing seedling recruitment, forest community structure, and dynamics [7,10-13]. The huge variation in natural systems induces meaningful challenges for higher plants in terms of their ability to grow and reproduce, compete with their neighbors for light and nutrients, and tolerate biotic and abiotic stresses.

Light is crucial for plant growth and development and both low and high light levels can limit the performance of a seedling [14]. Low irradiance decreases carbon gain and reduces seedling growth [15], whereas in high irradiance plants will have to face heat, desiccation, excessive irradiance, and ultraviolet radiation stresses. Coping with high irradiance requires protective adjustments of different orders [16], since excess light may cause photoinhibition [17]. Therefore, many plants show an extraordinary ability to adjust their morphology, physiology, and anatomy in relation to different light environments through acclimation that allows them to efficiently use the light available and avoid photodamage at the same time [14,18-20]. Furthermore, the response of plants to different gradients of photosynthetically active radiation (PAR) varies among species, which results in altered patterns of growth and biomass allocation $[14,21,22]$.

Seedlings of pioneer species exposed to high light conditions should develop sun leaves with more and/or larger mesophyll layers [23], higher stomatal density [18,24], and higher photosynthetic capacity $[18,23,25,26]$ than shaded leaves. Sun leaves may thus have higher carbon uptake rates per leaf area, but this comes at a cost of higher leaf respiration rates and more rapid water loss per leaf area [12]. According to Zhang et al. [27], sun branches with high photosynthetic rates on a leaf area basis may require a larger xylem area per $\mathrm{L}_{\mathrm{A}}$, as well as a larger phloem area per $\mathrm{L}_{\mathrm{A}}$, than shade branches. This implies larger stem diameters for the same area of supported leaves. On the other hand, pioneer species that would successfully grow in the understory have to develop a whole new suite of ecophysiological traits to adapt to low PAR [28,29] and a low red/far red ratio (R/FR), since plant developmental responses to shade in the understory are the combination of reductions in PAR and changes in spectral quality with a lower R/FR [30].

According to Smith [31], R/FR in the understory varies from 0.05 to 0.70 ; thus, R/FR under dense canopy is reduced when compared to open areas $(R / F R \geq 1.15)$. These changes are detected by phytochrome that plays a key role in light-regulated vegetative development and metabolism [32-34]. Due to a low $\mathrm{R} / \mathrm{FR}$, the plants can detect shade and the reflection produced by the neighboring plants [35,36]. Therefore, the first seedling photomorphological response to shade (low R/FR) is shoot elongation [33], concomitant with an increase in the individual leaf size and petiole length [37,38]. These photomorphological responses, which are called shade avoidance (SA), originate from the phytochrome-mediated perception of FR radiation scattered from the leaves of neighbors and provide early warning of shading. When successful, SA results in specific plants overtopping their neighbors. Reductions in the $\mathrm{R} / \mathrm{FR}$ ratio favor the conversion of the phytochrome molecules into their inactive form. Therefore, SA must be suppressed under high R/FR. In this sense, SA is due to the relief of suppression rather than the induction of physiological responses [39].

Enterolobium contortisiliquum (Vell.) Morong, commonly named tamboril or pacara earpod tree, is a member of the Leguminosae-Mimosoideae that occurs in natural forest formations, mainly in the Atlantic Forest [40]. However, its occurrence is widespread, and it can be found in the ecotones of the savanna-forest boundary domains [28] as well as in the xeric shrubland and thorn forest "caatinga" domain in northeastern Brazil. At the southern part of Brazil, it can also be found in seasonal tropical and subtropical forests, open fields, and in shrub sandspits. It occurs in Argentina, Bolivia, Paraguay, and Uruguay [41], and lately has been introduced into Florida, USA [42]. Tamboril has been used to recover degraded areas because of its rapid growth. Kageyama [17], characterized tamboril as a tree that had a very good performance in low light conditions, with performance characteristic of species belonging to later successional stages. In fact, some authors have found it being recruited for all stages of the forest succession [43]. Nevertheless, the low number of ecophysiological studies along with 
sometimes contradictory results found for this species may hinder or even jeopardize the use of this species in reforestation programs.

This paper aims to determine which types of acclimation, in relation to variation in PAR and the spectral quality of three light environments, might account for such a wide spectrum of recruitment niches adopted by E. contortisiliquum in the forest succession. Additionally, we aim to provide advice concerning its potential for the restoration of degraded areas or the maintenance of already functional forests, as well as for seedling production. We hypothesized that the reduction of R/FR to an understory level would not compromise the growth and survival of tamboril seedlings. Since E. contortisiliquum is classified as a pioneer species, we also hypothesized that seedlings of tamboril grown in the full sun would have better outcomes after they were transplanted into open fields.

\section{Material and Methods}

\subsection{Site and Plant Material}

The present study was conducted in the dependencies of the Plant Physiology Division that belongs to the Biology Department of Biology in the University of Lavras (UFLA), located in Lavras, Minas Gerais $\left(21^{\circ} 14^{\prime} 42^{\prime \prime} \mathrm{S}, 45^{\circ} 00^{\prime} 00^{\prime \prime} \mathrm{W}\right)$, Brazil. Young seedlings of tamboril were germinated from seeds gathered in Coronel Murta county located in the north of Minas Gerais $\left(16^{\circ} 37^{\prime} 8^{\prime \prime} \mathrm{S}, 42^{\circ} 10^{\prime} 55^{\prime \prime} \mathrm{W}\right)$ in early July 2012, being immediately sown in ten-centimeter-deep plastic trays on 2 August 2012, without any type of pre-germination treatment. On 13 September 2012, the nearly 15-cm-tall seedlings were transplanted to four-liter plastic bags containing a mix of soil, manure, and sand in a ratio of 3:1:1, and left in the shade to acclimate after transplant. After a month, seedlings were fertilized regularly following recommendations for tree seedlings [44]. First, we used a half-strength modified Hoagland solution, which contained all macro and micronutrients essential to plant development; afterwards a full-strength modified Hoagland solution was furnished together with watering to keep the plants well-watered throughout the experimental period. After 43 days of transplant, the 80-day-old seedlings of tamboril were moved into a greenhouse covered with low-density transparent plastic and then distributed among three light environments: FS—an environment with no shade screen and conditions similar to full sun, namely, $100 \%$ of PAR with an average R/FR of 1.66; S-environment with Sombrite ${ }^{\circledR}$ shade net (Equipesca, Campinas, SP, Brazil) that allowed an average reduction of $62 \%$ of the PAR and an average R/FR of 1.54; and I-environment with an Insulfilm ${ }^{\circledR}$ (Insulfilm, São Paulo, Brazil) shade film with an average reduction of $76 \%$ of the PAR and an R/FR of 0.69 . Thus, environment $I$ also modified the light spectral quality in the R/FR spectrum, thereby simulating understory conditions. The Insulfilm treatment provided $24 \%$ of ambient light plus low R/FR, which are approximately the conditions found in dense savanna woodland, the densest vegetation type in the Brazilian savanna, where mean daily photosynthetic photon flux density measured at a height of $10 \mathrm{~cm}$ from the soil is $19 \%$ of the full sun [45]. During the experiment, all the plants were sprayed once with the pyrethroid insecticide Keshet 25 EC (half-strength), to control Aphis spp., which especially attacked the seedlings under I (low R/FR).

\subsection{Growth Analyses}

Most of the growth traits were measured from seven $(n=7)$ 165-day-old seedlings on their 85th day after induction (DAI) of the treatments in each light environment. For growth analysis the seedling height $(\mathrm{h})$ and stem diameter $\left(\mathrm{S}_{\mathrm{D}}\right)$ were measured with a ruler and an electronic caliper fortnightly throughout a period of 78 days, beginning one week after the induction of treatments. The seedlings' shoots were cut at the stem base and separated into leaves and stems, roots were carefully removed from their pots by gently washing away the soil around them and collected in a 3.5-mesh sieve (São Jorge Ltda., Itaipava, RJ, Brazil). Total biomass $\left(\mathrm{T}_{\mathrm{M}}\right)$, plus biomass of the shoot $\left(\mathrm{SH}_{\mathrm{M}}\right)$, leaves $\left(\mathrm{L}_{\mathrm{M}}\right)$, stem $\left(\mathrm{S}_{\mathrm{M}}\right)$, and roots $\left(\mathrm{R}_{\mathrm{M}}\right)$ were obtained on the 85th DAI by drying seven 165 -day-old seedlings from each environment in an oven at $70{ }^{\circ} \mathrm{C}$ to constant mass. The seedlings' leaf 
number $\left(\mathrm{L}_{\mathrm{N}}\right)$ was counted during the last sampling, and the total leaf area $\left(\mathrm{L}_{\mathrm{A}}\right)$ and individual leaf size $\left(L_{S}\right)$ were obtained from photographs of the leaves, which were processed using the ImageTool ${ }^{\circledR} \mathrm{v}$. 3.0 software (UT Health, San Jose, CA, USA). Other morphological traits obtained were the specific leaf area (SLA), that is, $\frac{\mathrm{L}_{\mathrm{A}}}{\mathrm{L}_{\mathrm{M}}}$; the root:shoot ratio $(\mathrm{R} / \mathrm{S})$; the stem basal diameter, that is, basal stem area $\left(\mathrm{S}_{\mathrm{A}}=\frac{\pi \mathrm{S}_{\mathrm{D}}{ }^{2}}{4}\right)$; divided per $\mathrm{L}_{\mathrm{A}}\left(\mathrm{S}_{\mathrm{A}} / \mathrm{L}_{\mathrm{A}}\right)$; the $\mathrm{h}$ per $\mathrm{S}_{\mathrm{D}}$ ratio $\left(\mathrm{h} / \mathrm{S}_{\mathrm{D}}\right)$; the leaf area ratio $(\mathrm{LAR})$, that is, $\frac{\mathrm{L}_{\mathrm{A}}}{\mathrm{L}_{\mathrm{M}}}$; the leaf mass ratio (LMR), that is, $\frac{L_{M}}{T_{M}}$; the stem mass ratio (SMR), that is, $\left(\frac{S_{M}}{T_{M}}\right)$; the root mass ratio $(R M R)$, that is, $\left(\frac{R_{M}}{T_{M}}\right)$; the leafing intensity $(\mathrm{Li})$, that is, $\frac{L_{N}}{T_{M}}$; the absolute diameter growth rate $\left(S_{D} G R\right)$ given by the formula: $\frac{\left(\mathrm{S}_{\mathrm{D} 2}-\mathrm{S}_{\mathrm{D} 1}\right)}{\left(\mathrm{t}_{2}-\mathrm{t}_{1}\right)}$ where $\mathrm{t}$ is the time of sampling; the absolute height growth rate (hGR) given by the formula: $\frac{\left(h_{2}-h_{1}\right)}{\left(t_{2}-t_{1}\right)}$ where $t$ is the time of sampling; and finally, the Dickson quality index (dqi) $[16,26]$ was given by the formula: $d q i=\frac{\mathrm{T}_{\mathrm{M}}}{\left[\left(\frac{\mathrm{h}}{\mathrm{S}_{\mathrm{D}}}\right)+\left(\frac{\mathrm{SH}_{\mathrm{M}}}{\mathrm{R}_{\mathrm{M}}}\right)\right]}$.

\subsection{Biochemical Analysis}

The Chlorophyll $a(\mathrm{Chl} a)$, chlorophyll $b(\mathrm{Chl} b)$ and total chlorophyll $(\mathrm{Chl}(a+b))$, as well as total carotenoids (Cars) were quantified by the methodology described by Arnon [46] on the 115th DAI, using $0.1 \mathrm{~g}$ of fresh leaf material from 190-day-old seedlings, which were ground with $10 \mathrm{~mL}$ of $80 \%$ acetone in a mortar using a pestle inside a dark room illuminated with green light. Chlorophyll extracted with acetone solution was collected into test tubes by filtering the homogenate and protected from light by covering with aluminum foil. Then the final volume of the filtrate was filled up to $25 \mathrm{~mL}$ with $80 \%$ acetone. Concentrations of $\mathrm{Chl} a, \mathrm{Chl} b$, and $\mathrm{Chl}(a+b)\left(\mathrm{mg}^{-1}\right.$ of tissue) were quantified by reading the extracts spectrophotometrically at 470,663, and $645 \mathrm{~nm}$ and applying the formulas [47]:

$$
\begin{gathered}
\text { Chl } a=12.7(\mathrm{~A} 663)-2.69(\mathrm{~A} 645) \times V \times 10^{3} \times W, \\
\text { Chl } b=22.9(\mathrm{~A} 645)-4.68(\mathrm{~A} 663) \times V \times 10^{3} \times W, \\
\text { Chl }(a+b)=20.2(\mathrm{~A} 645)+8.02(\mathrm{~A} 663) \times V \times 10^{3} \times W, \\
\text { Cars }=(1000 \times \mathrm{A} 470-1.82 \mathrm{Chl} a-85.02 \mathrm{Chl} b) / 198,
\end{gathered}
$$

where

$\mathrm{A}=$ absorbance at specific wavelengths

$V=$ final volume of chlorophyll extract

$W=$ fresh weigh of tissue extracted

and then they were estimated on a mass basis-represented by the subscript $\mathrm{M}$ in the terms between parentheses ( $\mathrm{Chl}\left(a+b_{\mathrm{M}}\right), \mathrm{Chl} a_{\mathrm{M}}, \mathrm{Chl} b_{\mathrm{M}}$, and Cars $\left.\mathrm{M}\right)$ and on an area basis-represented by the subscript ${ }_{\mathrm{A}}$ in the terms between parentheses $\left(\mathrm{Chl}\left(a+b_{\mathrm{A}}\right), \mathrm{Chl} a_{\mathrm{A}}, \mathrm{Chl} b_{\mathrm{A}}\right.$ and Cars $\left.\mathrm{A}\right)$ [47]. The content of total leaf nitrogen $(\mathrm{N})$ present in the leaves of seven 190-day-old seedlings collected at 115th DAI was determined by the Kjeldahl method, and the total leaf phosphorus $(\mathrm{P})$ was determined through a colorimetric method described by Silva [48]. Afterwards, we calculated both element contents in terms of $\mathrm{L}_{\mathrm{M}}$, that is, the content of nitrogen on a mass basis $\left(\mathrm{N}_{\mathrm{M}}\right)$ and phosphorus on a mass basis $\left(\mathrm{P}_{\mathrm{M}}\right)$ and in terms of $\mathrm{L}_{\mathrm{A}}$, that is, the content of nitrogen on an area basis $\left(\mathrm{N}_{\mathrm{A}}\right)$ and phosphorus on an area basis $\left(\mathrm{P}_{\mathrm{A}}\right)$. The photosynthetic nitrogen-use efficiency (PNUE) was obtained by the quotient net assimilation $\left(A_{n}\right)$ per $N_{A}\left(A_{n} / N_{A}\right)$.

\subsection{Leaf Gas Exchange}

Leaf gas exchange was measured in the morning period between 09:30 and 10:30 a.m., with an infrared gas analyzer (Li-6400, LI-COR Biosciences, Lincoln, NE, USA) at 88 DAI, in 168-day-old seedlings using photosynthetic photon flux density of $1000 \mu \mathrm{mol} \mathrm{m}^{-2} \mathrm{~s}^{-1}$. The measurements for 
net assimilation $\left(A_{n}\right)$, transpiration $(E)$, stomatal conductance $\left(g_{s}\right)$, internal $\mathrm{CO}_{2}$ concentration $(\mathrm{Ci})$, water use efficiency WUE $\left(A_{n} / E\right)$, and carboxylation efficiency $\left(A_{n} / C i\right)$ were taken from healthy, completely expanded intact leaves.

\subsection{Anatomical Analyses}

The youngest mature leaves of seven plants in each treatment were collected at $112 \mathrm{DAI}$ and fixed in FAA 70 (formaldehyde, ethanol and glacial acetic acid) for $72 \mathrm{~h}$. Afterward, they were stored in ethanol 70\% [49]. The middle region of leaves underwent dehydration in an ethyl alcohol series, infiltration in synthetic resin, embedding, cutting in a semi-automated rotary microtome Yidi YD-335 (Jinhua Yidi Co., Zhejiang, China), dyeing using toluidine blue $1 \%$ with sodium borate $1 \%$ in $100 \mathrm{~mL}$ of distilled water, and then mounted on permanent slides [50]. Epidermal cuttings of the pinnules collected from the central part of leaflets were attached to glass slides with glue, which allowed the epidermis of the pinnule to be fixed on. Later they were washed in distilled water, dyed with safranin $1 \%$, and then covered with the slip in glycerinated water (1:1), all slides were photographed using a light microscope with an image capture system Olympus CX31 (Olympus, Tokyo, Japan) at a magnification of $20 \times$. The thickness of mesophyll, palisade parenchyma, and spongy parenchyma along with stomatal density, cell density, stomatal index, stomatal length, and stomatal width were measured using the ImageTool ${ }^{\circledR}$ software (UT Health, San Antonio, CA, USA).

\subsection{Experimental Design and Statistical Analysis}

This experiment was conducted in a completely randomized design with fifteen plants in each light treatment. The data collected were analyzed with analysis of variance (ANOVA) using the program SigmaPlot ${ }^{\circledR}$ version 11.0 (Systat Software, San Jose, CA, USA), with light environments as a factor. Data that did not satisfy the normality assumption were analyzed with Kruskal-Wallis' ANOVA on ranks to compare the treatments. The means and medians were compared by Tukey's honestly significant difference at $p<0.05$.

\section{Results}

During the experiment, the mean temperature $\left(\mathrm{T}_{\text {mean }}\right)$ in $F S$ environment was significantly larger than in the two shaded environments. High values of $T$ and low values of relative humidity resulted in a larger mean vapor pressure deficit (VPD) in FS compared to the other two environments. Larger values of VPD would inflict larger transpirational demand on the seedlings. The minimum temperature $\left(T_{\min }\right)$ did not vary significantly among the light conditions and the maximum temperature $\left(\mathrm{T}_{\max }\right)$ exhibited the same behavior as $\mathrm{T}_{\text {mean, }}$, being larger in $F S$ (Table 1).

Table 1. Atmospheric and spectral conditions of three light environments-full sun (FS), shade (S) and insulfilm (I)-during the experimental time for the growth of E. contortisiliquum seedlings. The abbreviated terms are the following: $\mathrm{T}_{\text {mim }}$ (minimum temperature), $\mathrm{T} \max$ (maximum temperature), $\mathrm{T}_{\text {mean }}$ (mean temperature), VDP (vapor pressure deficit) and R/FR (ratio red/far red light). The values with the same superscript letter in the lines are not significantly different by Tukey at $p<0.05$.

\begin{tabular}{cccc}
\hline \multirow{2}{*}{ Atmospheric Conditions } & \multicolumn{3}{c}{ Light Treatments } \\
\cline { 2 - 4 } & $\boldsymbol{F S}$ & $\boldsymbol{S}$ & $\boldsymbol{I}$ \\
\hline $\mathrm{T}_{\min }{ }^{\circ} \mathrm{C}$ & $19.1^{\mathrm{a}}$ & $19.2^{\mathrm{a}}$ & $19.2^{\mathrm{a}}$ \\
$\mathrm{T}_{\max }{ }^{\circ} \mathrm{C}$ & $45.8^{\mathrm{a}}$ & $34.8^{\mathrm{b}}$ & $35.5^{\mathrm{b}}$ \\
$\mathrm{T}_{\operatorname{mean}}{ }^{\circ} \mathrm{C}$ & $28.6^{\mathrm{a}}$ & $25.2^{\mathrm{b}}$ & $25.8^{\mathrm{b}}$ \\
VPD & $1.39^{\mathrm{a}}$ & $0.92^{\mathrm{b}}$ & $0.93^{\mathrm{b}}$ \\
$\mathrm{R} / \mathrm{FR}$ & $1.67^{2}$ & 1.54 & 0.69 \\
\hline
\end{tabular}


The shaded environments $S$ and $I$ displayed on average a reduction of $62 \%$ and $76 \%$ of PAR in relation to $F S$ environment (Figure 1). In the I environment, there was a large increase in irradiance above $700 \mathrm{~nm}$ in the region of FR light, demonstrating a change in the spectral quality in I environment, which displayed a R/FR ratio lower than in the $F S$ and $S$ treatments (Table 1). Therefore, the $I$ treatment emulated an understory environment for the seedlings growing in that light condition.

Accumulation of $\mathrm{T}_{\mathrm{M}}$ in 165-day-old tamboril seedlings at 85 DAI was $46 \%$ greater in FS than in $S$ and $90 \%$ higher in $F S$ than in $I$, with a difference of $30 \%$ between $S$ and $I$ (Figure $2 \mathrm{~A}$ ). Although displaying a larger variation (Figure 2B) than in the other two shaded environments, $\mathrm{L}_{\mathrm{M}}$ on average was $51.5 \%$ larger in $F S$ than in $I$ and the leaves in $S$ tended to have proportionally the same difference of biomass accumulation in I compared to $\mathrm{T}_{M}(29.9 \%)$. Following the same pattern, $\mathrm{S}_{\mathrm{M}}$ was $39.2 \%$ heavier in $F S$ compared to $S$ and $72.5 \%$ heavier in $F S$ than in $I$. Root mass $\left(R_{M}\right)$ displayed the highest differences in terms of biomass accumulation being $92.4 \%$ heavier in $F S$ than in $S$ and exhibiting an astounding $166.7 \%$ greater accumulation of root biomass in FS compared to $I$ (Figure 2). Thus, the R/S ratio of the seedlings at $85 \mathrm{DAI}$ were on average one and a half times larger in FS than in both shaded environments.

On the other hand, $\mathrm{L}_{\mathrm{A}}$ of tamboril was significantly larger in both shaded environments than in $F S$, being $117.2 \%$ larger in $S$ and $87.5 \%$ larger in I compared to $F S$, with a non-significant difference of only $14.5 \%$ between $S$ and $I$ (Table 2). Another important trait that accounts for shade acclimation, $\mathrm{L}_{\mathrm{N}}$, was also larger in $S$ than in $F S$, nonetheless the seedling growing in I just had a tendency of possessing larger $\mathrm{L}_{\mathrm{N}}$ than FS (Table 2). Slightly different from the previous trait, $\mathrm{L}_{S}$ was larger in both shaded environments when compared to $F S$ environment, and finally leaf intensity $\left(\mathrm{L}_{\mathrm{I}}\right)$-a trait that gives an idea of the seedling biomass mobilization to build leaf structure-behaved just like $\mathrm{L}_{S}$.

Seedlings at 69 and 85 DAI were taller in $S$ than in FS, and the ones in $I$ displayed a tendency of having a higher $\mathrm{h}$ than $F S$ (Figure $3 \mathrm{~A}$ ) that consequently resulted in greater hGR in $S$ than in FS and $I$ (Table 2). On the other hand, $S_{D}$-an interesting photosynthetic efficiency trait—was significantly larger in $F S$ and $S$ than in I (Figure $3 \mathrm{~B}$ and Table 2), which probably caused $S_{D}$ GR to have the same behavior of being greater in both $F S$ and $S$ when compared to seedlings in $I$ (Table 2). Transpirational flux of seedlings is normally affected by the $\mathrm{S}_{\mathrm{A}} / \mathrm{L}_{\mathrm{A}}$ ratio, which was greater in $F S$ than in $I$, and seedlings growing in $S$ displayed a tendency of being larger than those growing in $I$. Inversely, the $h / S_{D}$-a ratio used to indicate the hardiness of seedlings, where the smaller the better-was smaller in FS than in both shaded environments, indicating better hardened off seedlings in FS (Table 2).

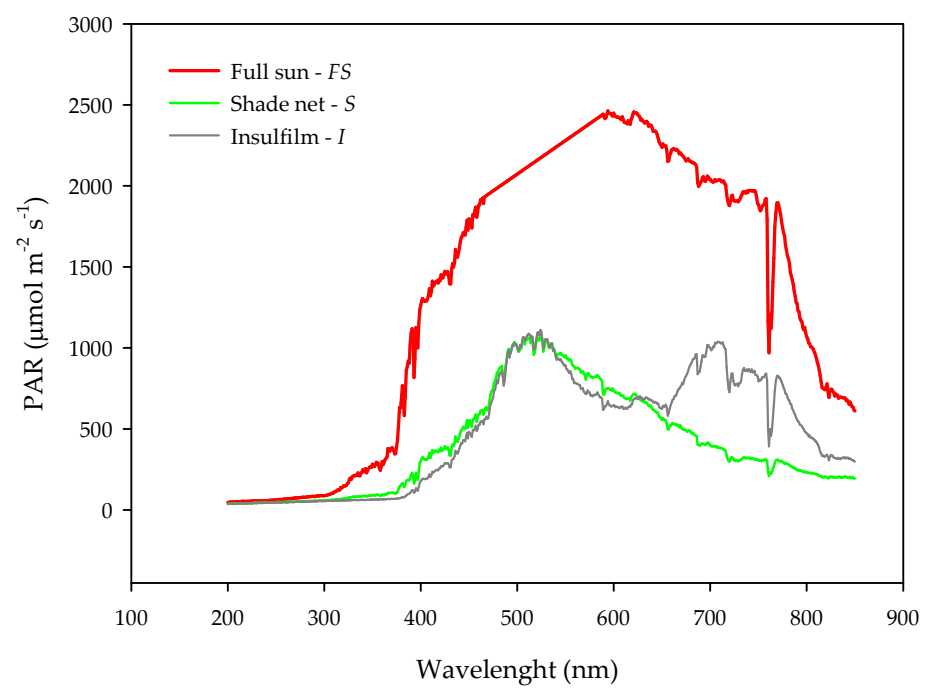

Figure 1. Typical photosynthetically active radiation per wavelength under three light conditions: Full sun-FS (red line); shade net—S (green line) and Insulfilm—I (gray line), mean values from three hours 8:00 a.m., 12:00 p.m. and 4:00 p.m.). Measurements were taken throughout the 80th DAI. 

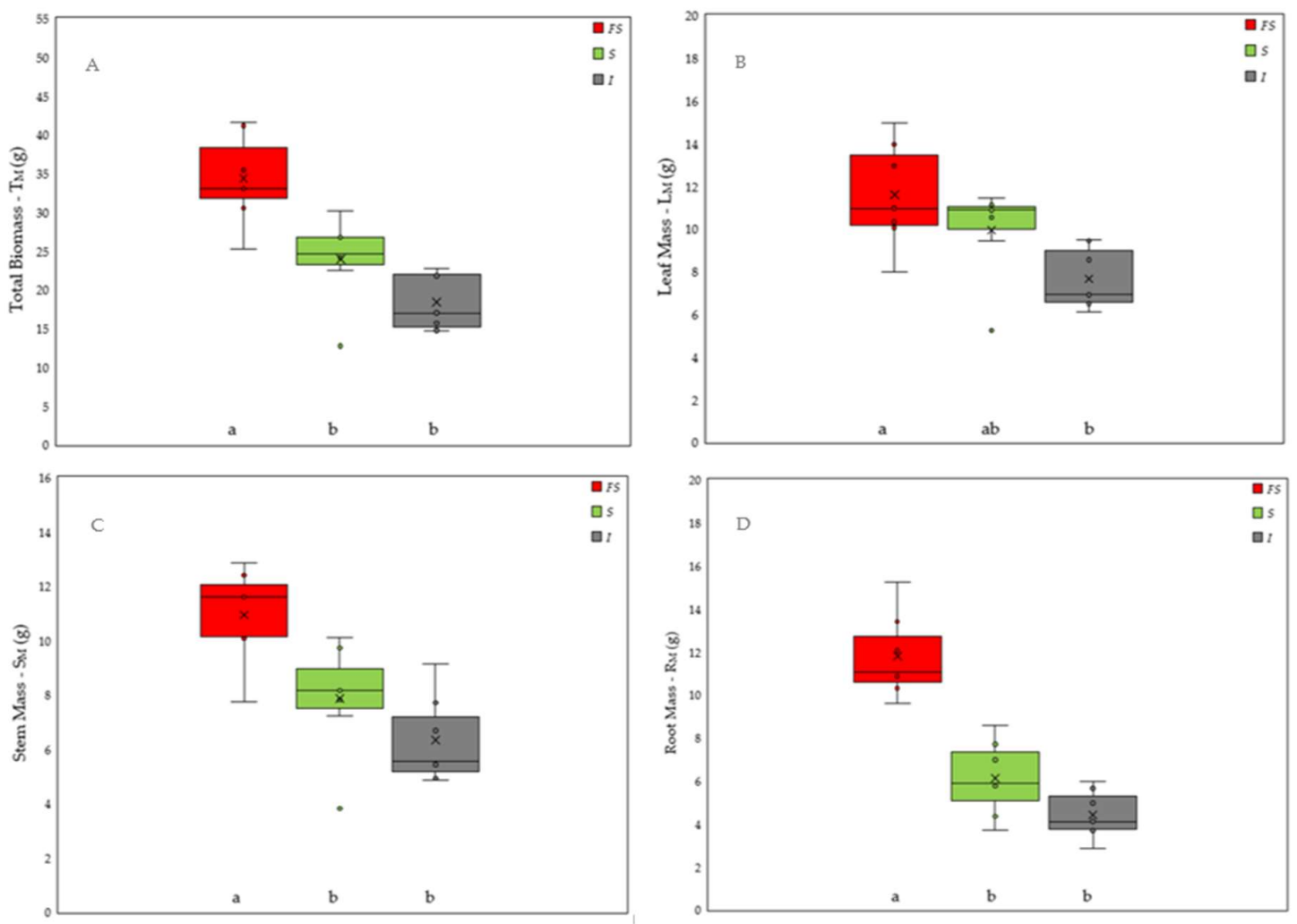

Figure 2. Effect of three light environments—full sun (FS), shade net (S) and insulfilm (I)—upon the (A) total mass $\left(\mathrm{T}_{\mathrm{M}}\right)$; (B) leaf mass $\left(\mathrm{L}_{\mathrm{M}}\right) ;(\mathbf{C})$ stem mass $\left(\mathrm{S}_{\mathrm{M}}\right)$; and $(\mathrm{D})$ root mass $\left(\mathrm{R}_{\mathrm{M}}\right)$ of E. contortisiliquum seedlings at 85 days after the induction of the treatments. Boxes with the same letter are not significantly different by Tukey's honestly significance difference at $p<0.05$, and the vertical bars represent the standard deviations.
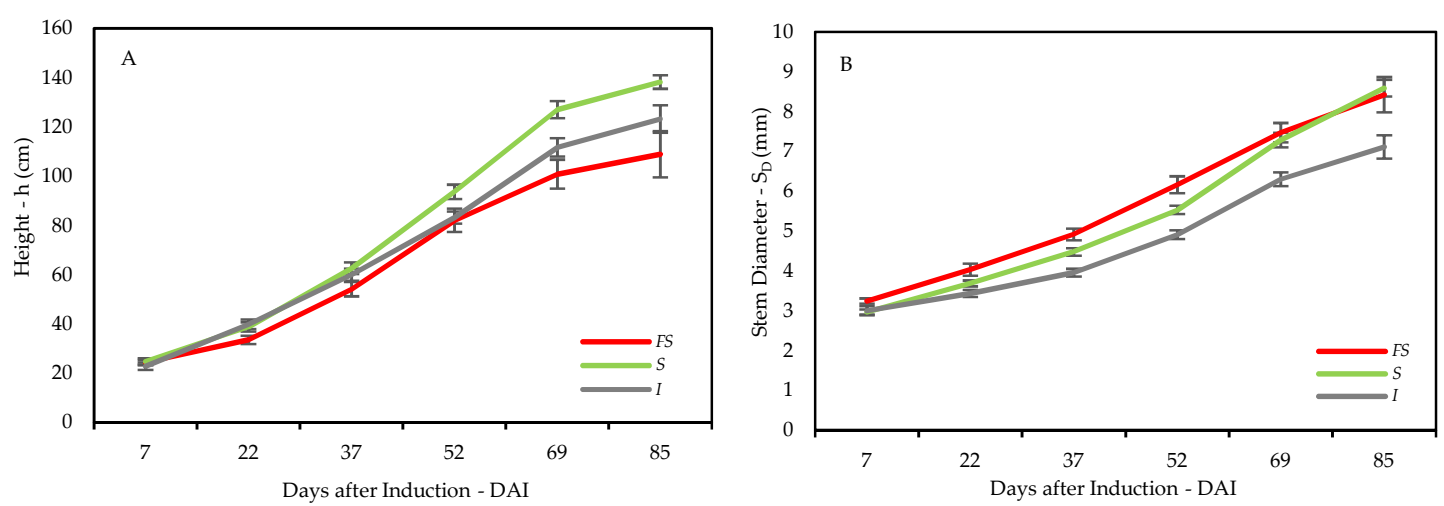

Figure 3. Effect of three light environments—full sun (FS), shade net $(S)$ and insulfilm $(I)$ - upon the growth values of average (A) height and (B) diameter of E. contortisiliquum throughout the experimental period. The vertical bars represent the standard errors of the means.

The seedlings exhibited the greatest SLA in I, which is a crucial characteristic for shade tolerance, being followed by $S$ seedlings and finally by the ones grown in $F S$ (Table 2), displaying therefore a linear response of this trait to light. Regarding biomass partitioning ratios, which give important information about plant architecture as well as acclimation, the seedings grown in both shade conditions had higher LMR, with similar values of 0.42 of total biomass being directed to the leaves, which represented an increase of $23.5 \%$ in leaf biomass partitioning to shade seedlings, while FS exhibited only 0.34 of 
biomass going to the leaves (Table 2). Regarding the SMR, seedlings did not exhibit any differences between the treatments with values ranging from 0.32 to 0.34 ; such a result seems to indicate that stem partition is a conservative trait in E. contortisiliquum. In its turn, RMR-an important trait for water acquisition-was higher in FS with 0.35 of the total biomass and both shade environments with non-significant differences of 0.26 and 0.24 for both $S$ and $I$, respectively (Table 2). The Dickson index, which used to evaluate the quality of seedlings produced, displayed very high indices in all three light conditions, however, the pioneer characteristics of E. contortisiliquum must have influenced the performance of the seedlings that exhibited the highest figures by seedlings grown in FS (2.26), followed by those in $S(1.25)$, with the ones grown in $I(0.89)$ displaying the lowest dqi values of all three (Table 2).

Table 2. Morphological and biometric characteristics of E. contortisiliquum seedlings grown in three different light environments-full sun (FS), shade net $(S)$ and insulfilm $(I)$. Mean and median $\left(^{*}\right)$ values with the same superscript letters in a line do not differ significantly at $p<0.05$ by Tukey, and the values in parentheses are the standard deviations. The abbreviated terms are the following: $\mathrm{L}_{\mathrm{A}}$ (leaf area), $\mathrm{L}_{\mathrm{N}}$ (number of leaves per plant), $\mathrm{L}_{\mathrm{S}}$ (leaf size), $\mathrm{L}_{\mathrm{I}}$ (leaf intensity), $\mathrm{h}$ (height), hGR (height growth rate), $S_{D}$ (stem diameter), $h / S_{D}$ (height per stem diameter), $S_{D} G R$ (stem diameter growth rate), $\mathrm{R} / \mathrm{S}$ (root/shoot ratio), $\mathrm{S}_{\mathrm{A}} / \mathrm{L}_{\mathrm{A}}$ (stem area/leaf area ratio), SLA (specific leaf area), LAR (leaf area ratio), LMR (leaf mass ratio), SMR (stem mass ratio), RMR (root mass ratio) and dqi (Dickson quality index).

\begin{tabular}{|c|c|c|c|}
\hline \multirow{2}{*}{ Traits } & \multicolumn{3}{|c|}{ Light Treatments } \\
\hline & FS & $S$ & $I$ \\
\hline $\mathrm{L}_{\mathrm{A}}\left(\mathrm{dm}^{2}\right)$ & $23.2( \pm 5.0)^{b}$ & $50.4( \pm 6.0)^{\mathrm{a}}$ & $43.5( \pm 6.8)^{\mathrm{a}}$ \\
\hline $\mathrm{L}_{\mathrm{N}}\left(\right.$ leaves plant $\left.{ }^{-1}\right)$ & $10.9( \pm 2.0)^{b}$ & $14.0( \pm 1.3)^{\mathrm{a}}$ & $12.7( \pm 1.6)^{a b}$ \\
\hline $\mathrm{LS}_{\mathrm{S}}\left(\mathrm{cm}^{2}\right)$ & $21.8( \pm 2.5)^{b}$ & $36.6( \pm 3.8)^{\mathrm{a}}$ & $33.9( \pm 4.1)^{\mathrm{a}}$ \\
\hline $\mathrm{L}_{\mathrm{I}}\left(\right.$ leaves $\left.\mathrm{g}^{-1}\right)$ * & $0.31^{\mathrm{b}}$ & $0.57^{\mathrm{a}}$ & $0.68^{\mathrm{a}}$ \\
\hline $\mathrm{h}(\mathrm{cm})^{*}$ & $115.4^{\mathrm{b}}$ & $136.2^{\mathrm{a}}$ & $120.5^{\mathrm{ab}}$ \\
\hline $\operatorname{hGR}\left(\mathrm{cm} \mathrm{day}^{-1}\right)$ & $1.37^{\mathrm{b}}$ & $1.67^{\mathrm{a}}$ & $1.38 \mathrm{~b}$ \\
\hline $\mathrm{S}_{\mathrm{D}}(\mathrm{mm})^{*}$ & $8.63^{a}$ & $8.53^{\mathrm{a}}$ & $7.06 \mathrm{~b}$ \\
\hline $\mathrm{h} / \mathrm{S}_{\mathrm{D}}\left(\mathrm{cm} \mathrm{mm}^{-2}\right)^{*}$ & $13.8^{\mathrm{b}}$ & $17.4^{\mathrm{a}}$ & $17.7^{\mathrm{a}}$ \\
\hline $\mathrm{S}_{\mathrm{D}} \mathrm{GR}\left(\mathrm{mm} \mathrm{day}^{-1}\right) *$ & $0.072^{\mathrm{a}}$ & $0.072^{\mathrm{a}}$ & $0.052^{b}$ \\
\hline$R / S$ & $0.52( \pm 0.06)^{\mathrm{a}}$ & $0.36( \pm 0.07)^{b}$ & $0.32( \pm 0.07)^{b}$ \\
\hline $\mathrm{S}_{\mathrm{A}} / \mathrm{L}_{\mathrm{A}}\left(\mathrm{cm}^{2} \mathrm{~m}^{-2}\right)^{*}$ & $0.245^{\mathrm{a}}$ & $0.116^{\mathrm{ab}}$ & $0.090^{\mathrm{b}}$ \\
\hline $\operatorname{SLA}\left(\mathrm{cm}^{2} \mathrm{~g}^{-1}\right)$ & $284.2( \pm 18.2)^{\mathrm{c}}$ & $373.3( \pm 28.2)^{b}$ & $452.5( \pm 43.9)^{\mathrm{a}}$ \\
\hline $\operatorname{LAR}\left(\mathrm{cm}^{2} \mathrm{~g}^{-1}\right)$ & $106.1( \pm 22.4)^{c}$ & $149.4( \pm 15.9)^{b}$ & $190.1( \pm 20.0)^{\mathrm{a}}$ \\
\hline $\operatorname{LMR}\left(\mathrm{g} \mathrm{g}^{-1}\right)$ & $0.34( \pm 0.02)^{b}$ & $0.42( \pm 0.04)^{\mathrm{a}}$ & $0.42( \pm 0.03)^{a}$ \\
\hline $\operatorname{SMR}\left(\mathrm{g} \mathrm{g}^{-1}\right)$ & $0.32( \pm 0.02)^{\mathrm{a}}$ & $0.33( \pm 0.02)^{\mathrm{a}}$ & $0.34( \pm 0.03)^{a}$ \\
\hline $\operatorname{RMR}\left(\mathrm{g} \mathrm{g}^{-1}\right)$ & $0.35( \pm 0.02)^{\mathrm{a}}$ & $0.26( \pm 0.04)^{b}$ & $0.24( \pm 0.04)^{b}$ \\
\hline$d q i$ & $2.26( \pm 0.23)^{a}$ & $1.25( \pm 0.29)^{\mathbf{b}}$ & $0.89( \pm 0.17)^{c}$ \\
\hline
\end{tabular}

The $\mathrm{A}_{\mathrm{n}}$ of the seedling grown in FS presented the greatest value of all, followed by the seedling in $S$ and finally by those in $I$. In fact, the increase in $A_{n}$ was linearly related to the increase in $g_{s}$, which led to increases in E (Figure 4A,B), which were both higher in FS (Table 3). It was also observed that the seedlings did not show any differences between the treatments in terms of Ci and WUE. However, the seedlings grown in FS displayed a higher $\mathrm{A}_{n} / \mathrm{Ci}$ than the ones in $I$ and those grown in $S$ presented a trend of being larger than the ones in $I$ (Table 3 ).

With regards to the contents of both $\mathrm{N}_{\mathrm{M}}$ and $\mathrm{P}_{\mathrm{M}}$, the seedlings did not exhibit any differences between the light treatments. Nevertheless, seedlings grown in FS and $S$ showed a larger accumulation of $\mathrm{N}_{\mathrm{A}}$ and $\mathrm{P}_{\mathrm{A}}$ compared to those placed in I (Table 3).

Shading strongly influenced the concentration of $\mathrm{Chl}\left(a+b_{\mathrm{M}}\right)$ in $S$ and $I$, which exhibited expected higher levels of those photoreceptors compared to FS. The seedling in $I$ also displayed a larger quantity of $\mathrm{Chl} b_{\mathrm{M}}$ than FS. However, $\mathrm{Chl} b_{\mathrm{M}}$ only showed a tendency of being higher in $S$ seedlings compared to FS (Table 3), which apparently was an incompatible finding. Moreover, $\mathrm{Chl}(\mathrm{a} / \mathrm{b})$ ratio showed no statistical differences between the light treatments neither on mass nor on area basis, which was also an uncommon finding especially for shade seedlings that usually exhibit a higher concentration of 
$\mathrm{Chl} b$ compared to $\mathrm{Chl} a$. However, this result seems to reinforce an overall effort of shade seedlings to increase the whole bulk of both Chlorophylls (Chls) $a$ and $b$ in shade. Following a similar trend to improve light capture, Cars $_{M}$ were larger in $I$ with a tendency of being larger in $S$ compared to $F S$ (Table 3). On the other hand, the $\mathrm{Chl}\left(a+b_{\mathrm{A}}\right), \mathrm{Chl} a_{\mathrm{A}}$ and $\mathrm{Chl} b_{\mathrm{A}}$ were greater in seedlings grown in $S$ than in both extreme light environments $F S$ and $I$, again an interesting finding, especially comparing both shade seedlings, where the reduction of R/RF in I negatively affected the concentration of Chls. Finally, $\mathrm{Cars}_{\mathrm{A}}$, in its turn, did not exhibit any significant differences.
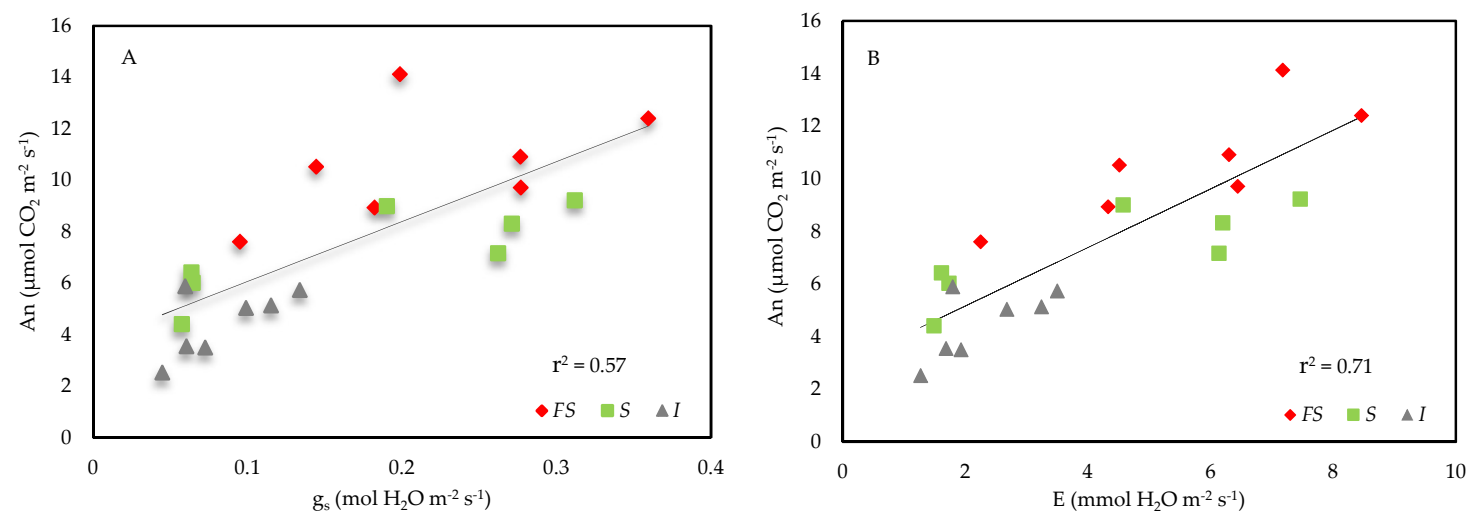

Figure 4. Effect of three light environments—full sun (FS), shade $(S)$ and insulfilm (I)—upon the net photosynthesis $\left(\mathrm{A}_{\mathrm{n}}\right)$ of E. contortisiliquum in relation to $(\mathbf{A})$ the stomatal conductance $\left(\mathrm{g}_{\mathrm{s}}\right)$ and $(\mathbf{B})$ the transpiration (E) of the seedlings. Both linear regressions were significant at $p<0.01$ with coefficients of determination $\left(\mathrm{r}^{2}\right)$ of 0.57 for $\mathrm{g}_{\mathrm{s}}$ and 0.71 for $\mathrm{E}$.

Table 3. Biophysical and biochemical characteristics of seedlings of E. contortisiliquum grown in three light environments—full sun $(F S)$, shade net $(S)$ and insulfilm $(I)$. Mean and median $\left(^{*}\right)$ values with the same superscript letters in a line do not differ significantly at $p<0.05$ by Tukey $(n=7)$, and the values in parentheses are the standard deviations. The abbreviated terms are the following: $A_{n}$ (net assimilation), $\mathrm{g}_{\mathrm{s}}$ (stomatal conductance), $\mathrm{E}$ (transpiration), $\mathrm{C}_{\mathrm{i}}$ (internal $\left(\mathrm{CO}_{2}\right)$ ), $\mathrm{A}_{\mathrm{n}} / \mathrm{C}_{\mathrm{i}}$ (net assimilation/internal $\left(\mathrm{CO}_{2}\right)$ ratio), WUE (water use efficiency), $\mathrm{N}_{\mathrm{A}}$ (nitrogen per leaf area), $\mathrm{N}_{\mathrm{M}}$ (nitrogen per leaf mass), $\mathrm{P}_{\mathrm{A}}$ (phosphorus per leaf area), $\mathrm{P}_{\mathrm{M}}$ (phosphorus per leaf mass), PNUE (photosynthetic nitrogen use efficiency), $\mathrm{Chl}\left(a+b_{\mathrm{M}}\right)$ (total chlorophyll per leaf mass), $\mathrm{Chl} a_{\mathrm{M}}$ (chlorophyll $a$ per leaf mass), $\mathrm{Chl} b_{\mathrm{M}}$ (chlorophyll $b$ per leaf mass), Cars $\mathrm{M}$ (carotenoids per leaf mass), Chl $\left(a+b_{\mathrm{A}}\right)$ (total chlorophyll per leaf area), $\mathrm{Chl} a_{\mathrm{A}}$ (chlorophyll $a$ per leaf area), $\mathrm{Chl} b_{\mathrm{A}}$ (chlorophyll $b$ per leaf area), Cars $\mathrm{A}$ (carotenoids per leaf area) and $\mathrm{Chl}(a / b)$ (chlorophyll $a /$ chlorophyll $b$ ratio).

\begin{tabular}{|c|c|c|c|}
\hline \multirow{2}{*}{ Traits } & \multicolumn{3}{|c|}{ Light Treatments } \\
\hline & FS & $S$ & $I$ \\
\hline $\mathrm{A}_{\mathrm{n}}\left(\mu \mathrm{mol} \mathrm{CO} \mathrm{CO}_{2} \mathrm{~m}^{-2} \mathrm{~s}^{-1}\right)$ & $10.6( \pm 2.17)^{\mathrm{a}}$ & $7.2( \pm 1.75)^{b}$ & $4.5( \pm 1.29)^{c}$ \\
\hline $\mathrm{g}_{\mathrm{s}}\left(\mathrm{mol} \mathrm{H}_{2} \mathrm{O} \mathrm{m}^{-2} \mathrm{~s}^{-1}\right) *$ & $0.20^{\mathrm{a}}$ & $0.19^{\mathrm{a}}$ & $0.07^{\mathrm{b}}$ \\
\hline $\mathrm{E}\left(\mathrm{mmol} \mathrm{H}_{2} \mathrm{O} \mathrm{m}^{-2} \mathrm{~s}^{-1}\right) *$ & $6.29^{a}$ & $4.57 \mathrm{ab}$ & $1.93^{b}$ \\
\hline $\mathrm{C}_{\mathrm{i}}\left(\mu \mathrm{mol} \mathrm{mol}{ }^{-1}\right)$ & $193( \pm 68)^{\mathrm{a}}$ & $179( \pm 99)^{\mathrm{a}}$ & $179( \pm 62)^{\mathrm{a}}$ \\
\hline$A_{n} / C_{i}$ & $0.048^{a}$ & $0.037^{\mathrm{ab}}$ & $0.023^{\mathrm{b}}$ \\
\hline WUE $\left(\mu \mathrm{mol} \mathrm{CO} \mathrm{Cmol} \mathrm{H}_{2} \mathrm{O}^{-1}\right)$ & $2.06( \pm 0.66)^{\mathrm{a}}$ & $2.30( \pm 1.16)^{\mathrm{a}}$ & $2.04( \pm 0.58)^{\mathrm{a}}$ \\
\hline $\mathrm{N}_{\mathrm{A}}\left(\mathrm{g} \mathrm{m}^{-2}\right)$ & $1.02( \pm 0.14)^{a}$ & $0.92( \pm 0.08)^{\mathrm{a}}$ & $0.70( \pm 0.04)^{b}$ \\
\hline $\mathrm{N}_{\mathrm{M}}\left(\mathrm{g} \mathrm{kg}^{-1}\right)$ & $29.4( \pm 5.43)^{\mathrm{a}}$ & $33.9( \pm 2.28)^{\mathrm{a}}$ & $31.8( \pm 2.11)^{a}$ \\
\hline $\mathrm{P}_{\mathrm{A}}\left(\mathrm{g} \mathrm{m}^{-2}\right)^{*}$ & $0.048^{a}$ & $0.042^{\mathrm{a}}$ & $0.032^{\mathrm{b}}$ \\
\hline $\mathrm{P}_{\mathrm{M}}\left(\mathrm{g} \mathrm{kg}^{-1}\right)^{*}$ & $1.3^{\mathrm{a}}$ & $1.6^{\mathrm{a}}$ & $1.6^{\mathrm{a}}$ \\
\hline PNUE $\left(\mu \mathrm{mol} \mathrm{CO} \mathrm{C} \mathrm{N}^{-1} \mathrm{~s}^{-1}\right)$ & $10.3( \pm 0.07)^{\mathrm{a}}$ & $7.7( \pm 0.13)^{b}$ & $6.3( \pm 0.15)^{b}$ \\
\hline $\operatorname{Chl}\left(a+b_{\mathrm{M}}\right)\left(\mathrm{mg} \mathrm{g}^{-1}\right)$ & $9.13( \pm 1.97)^{b}$ & $15.07( \pm 2.57)^{\mathrm{a}}$ & $15.18( \pm 3.93)^{\mathrm{a}}$ \\
\hline $\mathrm{Chl} a_{\mathrm{M}}\left(\mathrm{mg} \mathrm{g}^{-1}\right)$ & $6.18( \pm 1.16)^{b}$ & $10.11( \pm 1.35)^{\mathrm{a}}$ & $9.91( \pm 2.10)^{\mathrm{a}}$ \\
\hline $\mathrm{Chl} b_{\mathrm{M}}\left(\mathrm{mg} \mathrm{g}^{-1}\right)$ & $2.96( \pm 0.97)^{b}$ & $4.96( \pm 1.32)^{\mathrm{ab}}$ & $5.27( \pm 1.95)^{\mathrm{a}}$ \\
\hline $\operatorname{Cars}_{M}\left(\mathrm{mg} \mathrm{g}^{-1}\right)$ & $1.61( \pm 0.46)^{b}$ & $2.03( \pm 0.24)^{a b}$ & $2.26( \pm 0.50)^{a}$ \\
\hline
\end{tabular}


Table 3. Cont.

\begin{tabular}{cccc}
\hline $\mathrm{Chl}\left(a+b_{\mathrm{A}}\right)\left(\mathrm{mg} \mathrm{m}^{-2}\right)$ & $318.6( \pm 63.7)^{\mathrm{b}}$ & $408.0( \pm 57.9)^{\mathrm{a}}$ & $261.3( \pm 72.9)^{\mathrm{b}}$ \\
$\mathrm{Chl} a_{\mathrm{A}}\left(\mathrm{mg} \mathrm{m}^{-2}\right)$ & $215.8( \pm 38.7)^{\mathrm{b}}$ & $274.5( \pm 34.1)^{\mathrm{a}}$ & $178.0( \pm 44.9)^{\mathrm{b}}$ \\
$\mathrm{Chl}_{\mathrm{A}}\left(\mathrm{mg} \mathrm{m}^{-2}\right)$ & $102.9( \pm 31.2)^{\mathrm{ab}}$ & $133.6( \pm 29.2)^{\mathrm{a}}$ & $81.9( \pm 30.4)^{\mathrm{b}}$ \\
$\mathrm{Cars}_{\mathrm{A}}\left(\mathrm{mg} \mathrm{m}^{-2}\right)$ & $56.8( \pm 18.2)^{\mathrm{a}}$ & $55.3( \pm 7.07)^{\mathrm{a}}$ & $49.7( \pm 9.78)^{\mathrm{a}}$ \\
$\operatorname{Chl}^{\mathrm{a}}(a / b)$ & $2.18( \pm 0.42)^{\mathrm{a}}$ & $2.10( \pm 0.30)^{\mathrm{a}}$ & $2.16( \pm 0.45)^{\mathrm{a}}$ \\
\hline
\end{tabular}

E. contortisiliquum has naturally thin, slender, and hypostomatic leaves, which suffered high-light acclimation in practically all foliar anatomical traits analyzed (Table 4). Except for stomatal width, which only displayed significant differences in $I$ leaves compared to $F S$ and $S$, all the other traits were significantly different between high-light $(F S)$ and both shade conditions ( $S$ and $I$ ). In fact, such modifications were even evident between the two shade treatments with $I$ seedlings exhibiting the lowest values for traits such as stomatal density, stomatal length, mesophyll thickness, parenchyma palisade and parenchyma spongy, demonstrating a linear acclimation of those characteristics to the light condition with the intensification of their reduction with low R/FR conditions in $I$ (Table 4).

Table 4. Anatomical traits of seedlings of E. contortisiliquum grown in three light environments-full sun $(F S)$, shade net $(S)$, and insulfilm $(I)$. Mean and median $\left(^{*}\right)$ values with the same superscript letters in a line do not differ significantly by Tukey at $p<0.05$, and the values in parentheses are the standard deviations.

\begin{tabular}{cccc}
\hline \multirow{2}{*}{ Traits } & \multicolumn{3}{c}{ Light Treatments } \\
\cline { 2 - 4 } & $\boldsymbol{F S}$ & $S$ & $\boldsymbol{I}$ \\
\hline Stomatal density (Stomas mm $\left.^{-2}\right)^{*}$ & $475^{\mathrm{a}}$ & $331^{\mathrm{b}}$ & $268^{\mathrm{c}}$ \\
${\text { Cell density }\left(\text { cells mm }^{-2}\right)^{*}}^{\text {Stomatal index }}$ & $2050^{\mathrm{a}}$ & $1525^{\mathrm{b}}$ & $1625^{\mathrm{b}}$ \\
Stomatal length $(\mu \mathrm{m})^{*}$ & $0.24( \pm 0.02)^{\mathrm{a}}$ & $0.21( \pm 0.02)^{\mathrm{b}}$ & $0.17( \pm 0.02)^{\mathrm{c}}$ \\
Stomatal width $(\mu \mathrm{m})$ & $18.82^{\mathrm{a}}$ & $17.86^{\mathrm{b}}$ & $16.74^{\mathrm{c}}$ \\
Mesophyll thickness $(\mu \mathrm{m})^{*}$ & $8.77( \pm 1.07)^{\mathrm{a}}$ & $8.95( \pm 0.98)^{\mathrm{a}}$ & $8.29( \pm 0.94)^{\mathrm{b}}$ \\
Parenchyma Palisade $(\mu \mathrm{m})^{*}$ & $43.40^{\mathrm{a}}$ & $38.10^{\mathrm{b}}$ & $22.70^{\mathrm{c}}$ \\
${\text { Parenchyma Spongy }(\mu \mathrm{m})^{*}}^{*}$ & $27.74^{\mathrm{a}}$ & $22.28^{\mathrm{b}}$ & $13.58^{\mathrm{c}}$ \\
\hline
\end{tabular}

\section{Discussion}

\subsection{Growth and Physiological, Morphologica,l and Anatomical Adjustments to Light}

The tamboril seedlings grown in FS displayed a larger $T_{M}$ accumulation when compared to the seedlings cultivated in $S$ and $I$ environments as a consequence of the largest $A_{n}$ in the highest light condition. Souza et al. [51] also found larger values of $A_{n}$ and biomass accumulation for seedlings of E. contortisiliquum grown in high irradiance throughout the experimental period. Hoffman \& Franco [28] classified E. contortisiliquum as a pioneer forest species that has a higher net assimilation rate (NAR) compared to other forest species studied, which presents a decrease or just a slight increase in NAR in full sun when compared to shade. On the other hand, it is well-known that plants growing in shaded environments invariably diminish their photosynthetic capacity and light compensation point as a physiological adjustment due to low light availability [52,53], like the tamboril seedlings in both shaded conditions ( $S$ and $I$ ) in our study (Table 3 and Figure $4 \mathrm{~A}$ ). Despite the lower $A_{n}$ in shade, there was a compensatory effect of morphoanatomical adjustments such as higher SLA, LAR, and LMR in both shaded conditions that led to a larger $\mathrm{L}_{\mathrm{A}}$ in those environments. This greater $\mathrm{L}_{\mathrm{A}}$, in turn, allowed the plants to maintain their vegetative growth and accumulation of overall biomass throughout the whole experimental period. The behavior of assimilation and growth is strong evidence for the adjustment of E. contortisiliquum to low PAR and a lower R/FR. According to Li et al. [54], 
the relative influence of functional traits on growth rate (RGR) may vary with environmental conditions, especially light availability. If the RGR is primarily determined by SLA under low irradiance and by NAR under high irradiance, the compensatory influences of SLA and NAR on RGR between conditions of low and high irradiance would reduce variation in plant growth in heterogeneous light environments.

Curiously, Lima et al. [55] encountered a surprising larger $\mathrm{T}_{\mathrm{M}}$ accumulation as well as longer roots in 120-day-old seedlings of E. contortisiliquum grown in $80 \%$ and $50 \%$ of shade instead of in higher irradiance conditions ( $30 \%$ and full sun). These results, especially for the roots, are opposite to what is generally observed for biomass allocation and trade-offs between shade and sun plants, which would invest more biomass in the shoot instead of the roots in shade conditions [28,56,57]. On the other hand, Melo et al. [58] found that 25-day-old tamboril seedlings had accumulated more $R_{M}$ in seedlings cultivated in higher irradiance, which also rendered a higher R/S in full sun and 20\% of shade. In their turn, Souza et al. [51] also found longer and heavier roots in sun plants than those grown in $70 \%$ shade at 90 and 245 days after transplant. In our study, seedlings grown in FS also displayed a larger $\mathrm{R}_{\mathrm{M}}$ than in both shaded environments, as well as a larger R/S and RMR in FS. (Table 2). A larger $\mathrm{R}_{\mathrm{M}}$ and consequently larger root system is a crucial trait for plants growing in drier sites such as the savanna woodlands. Pioneer forest species, although they have a suite of traits adapted to shade environments, are also adapted to high irradiances, nonetheless, they have low success being recruited into the Brazilian savanna woodlands [28]. Therefore, other characteristics are crucial for determining plant success in the savannas. While most forest pioneers exhibit high NAR - that is, high $A_{n}$ and high phenotypic plasticity, traits shared with savanna species-they also exhibit comparatively higher SLA and LAR along with a lower R/S under the same light environment [59], traits which are not adaptive either to low water availability and nutrient stress or higher fire frequency found in the savannas. Moreira et al. [29] found that two Dalbergia spp. L.f. displayed interspecific differences in leaf plasticity to light. In general, the phenotypic plasticity of Dalbergia miscolobium Benth. (savanna woodland species) was higher than that of Dalbergia nigra (Vell.) Allemao ex Benth. (forest species) for leaf-tissue characteristics, including leaflet thickness and leaf mass area (LMA). In our study E. contortisiliquum displayed lower SLA and lower LAR with a percentage difference of $45.7 \%$ and $56.7 \%$ between FS and I. This plasticity may facilitate the recruitment of this species into the savanna woodlands.

Higher $S_{D}$ and $S_{D} G R$ are good indicators of higher net assimilation in plants, and those traits were statistically similar in FS and $S$ seedlings at 69 and 85 DAI (149 and 165-day-old seedlings, respectively) (Figure 3B), demonstrating the efficient assimilation of the seedlings grown in S. Similarly, Lee et al. [30] observed that the collar diameter of all species studied was primarily affected by a lower R/FR. As expected, the seedlings grown in $S$ displayed lower $A_{n}$, compared to $F S$. Nevertheless, larger $L_{A}$ was able to offset that difference, allowing E. contortisiliquum to assimilate significant overall quantities of carbon in shade. Similarly, Souza et al. [51] firstly observed higher $S_{D}$ in sun plants than in shade plants at 180 days after transplanting; however, at the end of their experiment (270 days) the shade plants displayed significantly higher values of $S_{D}$ and $L_{N}$. Furthermore, the shade seedlings had higher $\mathrm{L}_{\mathrm{A}}$ throughout the experimental period. According to the carbon gain hypothesis, any trait that improves light use efficiency, such as a larger $\mathrm{L}_{\mathrm{A}}$, and thereby improves carbon gain, should increase shade tolerance [60]. Naves et al. [61] found a higher accumulation of $\mathrm{SH}_{\mathrm{M}}$ in 150-day-old seedlings of Cybistax antisyphilitica (Mart.) Mart. (an early secondary species used in mixed reforestation and found growing in both the savanna woodland and forests) in full sun and $71 \%$ shade compared to $66 \%$ and $44 \%$ shade. That may have been possible because C. antisyphilitica invested a larger total $L_{A}$ in $71 \%$ shade compared to the other light levels [61]. On the other hand, Tabebuia aurea (Silva Manso) Benth. \& Hook. f. ex S. Moore-a pioneer tree characteristic of the savanna domain [62]—suffered a reduction in its $S_{D}$ and $L_{A}$ in $70 \%$ and $95 \%$ shade compared to full sun and $50 \%$ shade in 70 -day-old seedlings [63]. In fact, the lower $\mathrm{L}_{\mathrm{A}}$ of T. aurea was influenced by a low SLA in $70 \%$ shade. Despite the great increase in SLA in 95\% shade, there was not an effective increase in $\mathrm{L}_{\mathrm{A}}$. The lower SLA in critical shade levels is a less flexible trait that is characteristic of plants adapted only to the higher irradiances 
of the savannas $[2,62]$. The present study demonstrates that E. contortisiliquum, although classified as a pioneer and adapted to high irradiances, displayed larger SLA in shade, a trait that if expressed at the right moment may positively influence $\mathrm{L}_{\mathrm{A}}$ and shade tolerance.

However, a larger $\mathrm{L}_{\mathrm{A}}$, due to a larger surface area per leaf volume, may decrease the control of water loss, thus increasing the probability of dehydration of the seedlings after transplanting to the open field [64]. The increase in irradiance in the open field is usually coupled with high temperatures, which might be a severe problem when leaf temperatures exceed the photosynthetic optimum, especially if water availability is low [65]. Moreover, the morphological adjustments leading to a lower $\mathrm{R} / \mathrm{S}$ and $\mathrm{S}_{\mathrm{A}} / \mathrm{L}_{\mathrm{A}}$ in shade seedlings may reduce essential water and nutrient absorption, causing the plants to lose their capacity to support the necessary high rates of photosynthesis and transpiration when they are transplanted to high irradiance environments. Abrams and Mostoller [66] observed that during a drought period gas exchange decreased more in shaded leaves than in sun leaves, even resulting in values of maximum assimilation $\left(A_{\max }\right)$ inferior to zero in shaded leaves because of higher respiration. Shade leaves could be more sensitive to drought and photothermal inhibition than sun leaves due to decreased $\mathrm{A}_{\max }$ coupled with decreased photosynthetic light-response. Moreover, fast-growing plants with high intrinsic capacities for photosynthesis have lower capacities for flexible thermal dissipation (lower maximal non-photochemical fluorescence quenching) than slow-growing species [16]. These characteristics may be crucial for the recovery of disturbed and degraded areas, if the success of reforesting programs depends on being able to withstand high irradiance conditions and water and temperature stresses [28]. These findings may be interpreted as a problem for the deployment of shade-grown seedlings when they are transplanted to full sun in open fields.

Several traits and characteristics of the sun leaves contributed to the high assimilation of tamboril seedlings in the FS treatment. As described by several authors, seedlings exposed to high light levels should develop sun leaves with more or larger mesophyll layers [23,52], higher LMA-that is, lower SLA [18] - higher stomatal density [18,24,52] and higher photosynthetic capacity [18,23,25,26,52]. Sun leaves generally have a higher E, responsible for cooling leaves in high irradiances, and, additionally, smaller and/or more slender leaves, such as the compound leaves of E. contortisiliquum, which have a reduced boundary layer resistance. Those smaller leaves adjust their temperature through better convective cooling that prevents overheating [65]. All of these traits are necessary for seedlings or juvenile trees of tamboril that are being recruited as pioneers in the open field. Furthermore, small $L_{A}$ combined with small stomatal size (Table 4) may help counteract reduced WUE in leaves with high $\mathrm{g}_{\mathrm{s}}$, offsetting water loss [67]. Such stomatal behavior may enable E. contortisiliquum to use water efficiently, which is a crucial characteristic for seedlings grown in full sun where water may become a limiting resource. Another important trait that influences transpiration in open fields is a larger $\mathrm{S}_{\mathrm{A}} / \mathrm{L}_{\mathrm{A}}$. The largest $\mathrm{S}_{\mathrm{A}} / \mathrm{L}_{\mathrm{A}}$, which was displayed by the seedlings in $F S$, is needed for the maintenance of a suitable transpirational flux in full sun conditions. Leaves of light-demanding tree species are characterized by higher rates of photosynthesis, respiration, and transpiration per unit leaf area than leaves of shade-tolerant tree species [68]. These high rates are supported by a larger vascular system that includes both xylem tissue to match higher transpiration rates per leaf area and phloem tissue to export the rapidly acquired sugars more effectively [27].

\subsection{Biochemical and Additional Physiological and Morphoanatomical Adjustments to Light}

Several studies have shown that individual leaves will increase their area and Chl content on a mass basis in shaded sites $[69,70]$. We found larger values of Chl $\left(a+b_{\mathrm{M}}\right)$ in both shade seedlings compared to FS. On the other hand, several sun leaves of different trees (Fagus sylvatica L., Carpinus betulus L., Populus nigra L.) exhibit on average a larger content of $\mathrm{Chl}\left(a+b_{\mathrm{A}}\right)$ than shaded leaves [54]. In our study, the $\mathrm{Chl}\left(a+b_{\mathrm{A}}\right)$ in $S$ seedlings was larger than in FS, while the ones grown in $I$ exhibited values statistically similar to those in $F S$, demonstrating a good adjustment of this species to improving light capture even in low R/FR conditions. Moreover, the fact that $\mathrm{Chl}\left(a+b_{\mathrm{A}}\right)$ was lower in 
I compared to $S$ is corroborated by some data where lower $\mathrm{Chl}(a+b)$ both on an area basis as well as on a mass basis were observed in plants grown with increased FR light [71]. According to the authors [71], lower Chls contents were probably not the result of a dilution of a similar amount of Chl throughout larger leaves, especially because, in our case, the same did not happen in $S$; this low chlorophyll concentration in plants treated with FR may be a direct effect of a low phytochrome photo-equilibrium on some aspect of chlorophyll biosynthesis. Complementarily, $\mathrm{Chl}(a / b)$ did not suffer any reduction in relation to shade; Souza et al. [51] found higher Chl $(a+b)$ for E. contortisiliquum plants in the shade and did not find any change in $\mathrm{Chl}(a / b)$ either. On the other hand, Lima et al. [55] found a lower Chl $(a / b)$ ratio and higher $\mathrm{Chl}(a+b)$ in the shade, indicating a high investment in light capture. Chl $a$ is the principal pigment used in the photochemical phase of photosynthesis [52], while Chl $b$ indicates more investment in the antenna complex, which increases light capture. In general, plants grown in shaded conditions show a low $\mathrm{Chl}(a / b)$ ratio due to slower degradation of $\mathrm{Chl} b$.

The $\operatorname{Cars}_{\mathrm{M}}$ were higher in $I$ than in FS and had a tendency to be higher in $S$ than in FS, whereas Cars $_{\mathrm{A}}$ was not different between any of the three light environments, suggesting a greater adjustment of auxiliary light-harvesting compounds in the shade. Similar results for Cars in $_{M}$ E. contortisiliquum were found by Lima et al. [55], even though their values were larger than ours; Fagus sylvatica, a broad-leaved species that tolerates very deep shaded conditions, had values more similar to ours of $1.56 \mathrm{mg} \mathrm{g}^{-1}$ in sun leaves and $2.29 \mathrm{mg} \mathrm{g}^{-1}$ in the shade [47]; Bertholletia excelsa Humb. \& Bonpl., Lecythidaceae also had larger quantities of Cars in shade seedlings [72]. Even though a high Chl $\left(a+b_{\mathrm{M}}\right)$ and high SLA are consistent with the primary demand of shade leaves for light-harvesting compounds, these results raise the question of whether investment in Cars is more important for shade than sun leaves. Analogous to our finds for SLA and Cars, many species of neotropical forest plants invested less in structural components and more in light-harvesting ones [73], as manifested by high SLA and enhanced mass-based accumulation of Chls and Cars. It seems that the plasticity of the photosynthetic apparatus of young plants will improve their capabilities for the capture of available energy (higher Cars) in shade environments, and additionally, will facilitate the quenching of the excess energy in high irradiances as a mechanism to prevent possible photoinhibition. Those molecules also help plants deal with the excess light and photo-oxidation in high irradiance environments $[6,16,74]$. Cars are regarded as the first line of defense against $\mathrm{O}_{2}$ singlet toxicity generated by photo-oxidation because of their high efficiency in ${ }^{1} \mathrm{O}_{2}$ quenching and their location close to the $\mathrm{Chl}$ molecules in the light-harvest complex (LHC) and the reaction centers of the photosystem I (PSI) and photosystem II (PSII) [75,76].

The $\mathrm{N}_{\mathrm{M}}$ in seedlings of E. contortisiliquum was not significantly different between sun and shade leaves, indicating a trade-off between light-harvesting structures (Chls and Cars) and light utilization components such as Rubisco [77]. Higher $\mathrm{N}_{\mathrm{A}}$ in sun leaves is consistent with the idea that $\mathrm{N}$ acquisition and allocation within canopies follows a gradient of light availability [66]. Greater $\mathrm{N}_{\mathrm{A}}$ in sun leaves of E. contortisiliquum was predominantly a function of a higher LMA, that is, lower SLA, which had larger PNUE. The increase in PNUE was probably caused by greater Rubisco content, while Chl content was reduced in FS compared to both shade conditions (Table 3). Concomitantly, $\mathrm{P}_{\mathrm{A}}$ also displayed similar behavior to $\mathrm{N}_{\mathrm{A}}$, increasing with LMA. A larger concentration of Rubisco may demand a larger pool of inorganic phosphate in chloroplasts to achieve more efficient carboxylation rates (An/Ci) as seen in FS and $S$ seedlings. The thickening of palisade parenchyma is a structural differentiation observed in sun leaves that results in increased photosynthetic rates under high irradiances [4,52,64] (Table 3). The greater development of chlorenchyma (mesophyll palisade) is usually associated with a reduction in SLA $[19,29,64,78]$, a characteristic observed in our study with E. contortisiliquum, as well as by Mazzanatti et al. [3] in seedlings of Heliocarpus popayanensis Kunth and Aegiphila integrifolia (Jacq.) Moldenke. On the other hand, shade leaves usually show a thinner palisade layer of mesophyll cells with a higher SLA (Tables 2 and 4), allowing the same amount of LHC tissues to be extended over a wider area [77]. Chloroplasts in shade increase light capture by increasing the proportion of light-harvesting chlorophyll a/b-binding (LHCB) proteins-the antenna complexes associated 
primarily with PSII $[77,79]$. The thinner leaves in I accumulated more Chl $b_{\mathrm{M}}$ and Cars $_{\mathrm{M}}$, which are important components of the antenna complexes in PSII, thus probably increasing the PSII:PSI ratio that is a characteristic of shade tolerant species [80].

\subsection{Shade Avoidance or Shade Tolerance? Additional Ecophysiological Strategies to Light Acclimation}

Growth in $\mathrm{h}$ is a very important SA response of light-demanding plants to low light availability in shade environments [80-82]. The seedlings of E. contortisiliquum were taller in S, with a tendency of being taller in I compared to FS. This behavior was evident at 69 DAI (149 days old) and persisted into the last sampling at 85 DAI (165 days old). On the other hand, Souza et al. [51] reported shorter stem length in shade seedlings of E. contortisiliquum (70\% of shade) compared to full sun seedlings during practically the whole experimental period. These results seem anomalous, since a lower R/FR is the main cause of stem elongation in shaded plants $[39,81,83]$. Phytochromes play an important role in SA responses as they are transformed into their inactive forms-relieving the suppression of SA-by FR radiation that was abundant in I (Figure 1). Therefore, one would expect even taller seedlings in $I$, which did not happen in our study. Phytochrome A is the primary photoreceptor responsible for perceiving and mediating various responses to FR such as the relief of SA suppression, while phytochrome $B$ is the predominant suppressor of SA responses in red light [39]. The net rate of stem elongation in shade is the balance of opposing forces, inhibition and promotion, and each one is regulated by light subject to the influence of hormones and endogenous rhythms [84]. Lessa et al. [85] found that very young seedlings of tamboril growing in complete darkness after germination were taller and heavier than those grown in light. Furthermore, the seeds of E. contortisiliquum do not appear to have any light requirements for germination, being classified as photoblasticly neutral.

Ballaré et al. [81] hypothesized that seedlings of shade-intolerant species would react to alterations in light condition caused by their neighbors with morphological changes that may influence the pattern of carbon assimilation and allocation at the whole-canopy level. For instance, increasing stem elongation that is triggered by a low R/FR in dense canopies, may diminish the quantity of carbon available for leaf area expansion or root growth, and thereby affect carbon acquisition by the canopy. The authors concluded that the carbon used to maintain an elongation response to low R/FR ratios would not be removed from a pool that would otherwise be allocated to other organs but would specifically come from an increase in net canopy photosynthesis. We found a reduction in allocation to roots (lower RMR) in the shade, which could have compensated for the opportunity cost associated with stem growth, especially in $I$. However, it did not result in any significant carbon allocation to stems in shade seedlings. The SMR was similar among the light treatments, without any significant differences (Table 2), demonstrating that the proportion of biomass allocated to stems is a conservative trait in E. contortisiliquum, which seems to prefer to invest in resource-harvesting organs instead. Similarly, Hoffman \& Franco [28] did not find any differences in the partitioning of stem biomass in sun or shade for eighteen young woody plants from the Brazilian savanna and forest systems. Nevertheless, we found a greater LMR (0.42) in both shaded conditions compared to FS (0.34), clearly demonstrating greater investment in leaves for light capture in both shade environments. E. contortisiliquum is a pioneer species that grows in forests where competition for light is extremely important, conferring an advantage to taller individuals with greater $\mathrm{L}_{\mathrm{A}}$ [28].

Further important traits for the acclimatization of E. contortisiliquum to shade environments were the increase in $\mathrm{L}_{S}, \mathrm{~L}_{\mathrm{N}}$, and $\mathrm{L}_{\mathrm{I}}$ in both shaded environments $(S$ and $I)$ in comparison to $F S$. These results also showed the conspicuous investment of tamboril for increasing $\mathrm{L}_{\mathrm{A}}$ in shade. On the other hand, 169-day-old seedlings grown in $F S$, besides having a diminished $\mathrm{L}_{\mathrm{A}}$, also had faster yellowing of the oldest leaves (visual observation) compared to the other two shade environments. Souza et al. [51] found that shade plants had a significantly longer leaf life span (LLS) (202.3 \pm 21.35$)$ when compared with sun plants $(168.4 \pm 15.42)$; LLS was identical to our visual observation of 169-day-old plants in FS whose older leaves were beginning to turn yellow. Poorter [86] also found a strong correlation between reduced crown exposure and longer LLS in 41 species from moist forest 
and dry forest in Bolivia. Tong and $\mathrm{Ng}$ [87] observed that each doubling of light intensity shortened the leaf lifespan of sun leaves in Shorea roxburghii G. Don by 70 days, and that of Acacia mangium Willd. by 40 days. Similar results were found by Mazzanatti et al. [3] studying Guazuma ulmifolia Lam. and Heliocarpus popayanensis Kunth, whose seedlings showed a reduction in $\mathrm{L}_{\mathrm{N}}$ due to a faster old leaf senescence in sun-grown plants. LLS is a functional trait that reflects the carbon balance of the whole plant $[22,26,88]$. A leaf with a more complex structure must live longer to pay back the costs of its construction and maintenance $[26,89,90]$. On the other hand, leaves with a simpler structure (thinner compound leaves), as in the case of the deciduous E. contortisiliquum will pay back their formation and maintenance costs in a shorter time. In general, leaf longevity in shaded environments is longer than in the sun [91]. Therefore, longer leaf longevity in E. contortisiliquum is an important ecophysiological adjustment affecting carbon gain, since shade tolerance may be defined as the maximization of light capture (larger $\mathrm{L}_{\mathrm{A}}$ ) along with the minimization of respiration costs for maintenance (thinner and longer-lived leaves) [18].

According to Walters and Reich [57], tolerant deciduous species minimize biomass losses by minimizing whole-plant respiration rates, but those rates may be accomplished by lowering of biomass turnover through low LMR and not necessarily by long LLS. For instance, T. aurea, a heliophyte, had very high LMR, higher than 0.52 for seedlings grown in $70 \%$ of shade, without necessarily increasing its $\mathrm{L}_{\mathrm{A}}$ in comparison to sun plants [63]. On the other hand, E. contortisiliquum reached much higher $L_{A}$ values with a LMR of only 0.42 in both shade levels, which represented a lower proportion of total biomass going to leaves. Unlike most tropical evergreens, shade tolerant deciduous species can acquire large fractions of their total carbon during short periods of higher irradiance when the overstory is leafless during the dry season, especially in the savanna woodlands [92]. They can then allocate this carbon to storage (leading to higher RMR in the sun) rather than investing all the carbon in new leaves [57]. Therefore, lower biomass loss (lower LMR) plus a shorter foliar-payback time (a less costly leaf means thinner leaves with high SLA) as well as an increased allocation to storage in short sunnier periods are important traits to phenotypically adjust growth rate in scarce light environments, which seems to be the case with tamboril.

In evergreen tropical rain forests with reduced seasonality, tree leaves may vary enormously in their longevity from some months up to several years. On the other hand, in temperate deciduous forests the LLS of nearly all large-leafed species is restricted from five to seven months [93]. E. contortisiliquum has approximately the same range of leaf longevity as those species [51]. Therefore, it would be of little advantage to invest in expensive, hard, and complex leaves for deciduous shade-tolerant species such as tamboril. Under such conditions, a positive relationship between SLA and shade tolerance can be found $[94,95]$. Light-demanding species in a moist forest usually have a high LAR to support growth, whereas light-demanding species in a dry forest usually have a low LAR, probably to diminish transpiration and water loss [86]. For tamboril, the very plastic behavior of LAR and SLA show a definite trade-off between low and high light availability. The ample phenotypic plasticity of E. contortisiliquum in both shade or sun conditions enables this species to grow successfully in extreme light conditions [51].

\subsection{Targeted Traits in the Nursery}

The seedlings of E. contortisiliquum had very high $d q i$ (0.2 being the lowest acceptable) [96,97] in all three light environments. However, the seedlings grown in FS had the largest dqi values, being followed by $S$ and finally by $I$ (Table 2 ). These results show that all the seedlings were in very good condition including the ones under $I$. Nonetheless, the results confirmed our expectation that FS would produce better plants for the open field, since they developed traits to resist water stress, a situation which can occur in the open field conditions and savanna. For instance, the RSR displayed a positive increase with PAR, with more than half of total dry matter being distributed to the roots in the high irradiance treatment. It is well established that a larger root system is important for plants to cope with drought periods, since a larger root system could provide a critical supply of water during 
those periods. The seedlings of E. contortisiliquum did not have any significant differences in WUE between the treatments, demonstrating that the larger root and vascular systems developed in FS were capable of coping with the highest $\mathrm{E}$ demands (Figure $4 \mathrm{~B}$ and Table 3 ) in sun.

The $h / S_{D}$ is also an important characteristic when it comes to seedling production. Researchers also mention that lower ratios of shoot/root and $\mathrm{h} / \mathrm{S}_{\mathrm{D}}$ are characteristics of better hardened off seedlings, which will probably adjust better in open field conditions [16,64]. Since the seedlings that displayed a higher $\mathrm{R} / \mathrm{S}$ ratio and lower $\mathrm{h} / \mathrm{S}_{\mathrm{D}}$ were grown in $F S$, we believe that seedlings of tamboril grown in full sun in the nursery, before they are transplanted to the open field, will probably be better hardened off to resist the environmental stresses of the field. Our suggestion does not agree with the conclusions drawn by Lima et al. [55], who recommended the cultivation of tamboril seedlings in the shade to produce more vigorous seedlings before transplanting to open fields, because the sun may affect the growth of tamboril negatively in the field. Although the cultivation of seedlings in full sun would probably require more watering, which could be a setback for seedling production, we still believe this procedure could provide stronger transplants as concluded by Claussen [98] and Mazzanatti et al. [3].

In a study conducted to recover a riparian degraded area, the direct sowing of tamboril into the field had a better result ( $42 \%$ survival) than transplanting potted seedlings (18\% survival) [75]. However, the potted seedlings were grown under a shade net before taking them to the open field. We would not recommend such a procedure for the reasons already discussed. Seedlings grown under the protection of a shade net may develop unfavorable traits and be unable to support the adverse conditions of the open field (high T and VPD) and consequently survive less. On the other hand, when using E. contortisiliquum as a late secondary or even as a light-demanding climax tree in natural or anthropogenic free-fall gaps or in mixed plantations under conspecific populations which allow a reasonable penetration of sunflecks (e.g., plantations of Anadenanthera spp. Speg.), we recommend the use of shade-grown seedlings for a better initial performance in the field.

\section{Conclusions}

E. contortisiliquum has ample capacity for ecophysiological acclimation that may facilitate its recruitment into various light gradient niches and explain its wide geographical distribution, as shown by previous empirical field observations. Due to its plasticity, it may even have an advantage over less plastic species when responding to possible climate change.

Seedlings grown in full sun in the nurseries will develop morphoanatomical and physiological traits that may enhance growth and survival, particularly when transplanted to the open field. Nonetheless, traits developed in the nursery in shaded conditions could help the successful installation and survival of tamboril seedlings into already established forests. Further studies are necessary to verify the survival of tamboril after transplanting into open fields.

Author Contributions: V.L.N., M.P. and J.P.R.A.D.B. conceived conceptual ideas and designed the study. V.L.N., E.M.d.C. and S.R. performed data analysis. V.L.N. and S.R. wrote the manuscript. V.L.N. conducted data sampling and the experiment maintenance.

Funding: This research received no external funding.

Acknowledgments: We would like to thank the Conselho Nacional de Pesquisa e Desenvolvimento (CNPq) and the Coordenadoria de Aperfeiçoamento de Pessoal de Nivel Superior (CAPES) for the scholarship and resources available to accomplish this work.

Conflicts of Interest: The authors declare no conflict of interest.

\section{References}

1. Valladares, F.; Laanisto, L.; Niinemets, U.; Zavala, M.A. Shedding light on shade: Ecological perspectives of understorey plant life. Plant Ecol. Div. 2016, 9, 237-251. [CrossRef]

2. Krause, G.H.; Koroleva, O.Y.; Dalling, J.W.; Winter, K. Acclimation of tropical tree seedlings to excessive light in simulated tree-fall gaps. Plant Cell Environ. 2001, 24, 1345-1352. [CrossRef] 
3. Mazzanatti, T.; Calzavara, A.K.; Pimenta, J.A.; Oliveira, H.C.; Stolf-Moreira, R.; Bianchini, E. Light acclimation in nursery: Morphoanatomy and ecophysiology of seedlings of three light-demanding neotropical tree species. Braz. J. Bot. 2016, 39, 19-28. [CrossRef]

4. Oguchi, R.; Hikosaka, K.; Hiura, T.; Hirose, T. Leaf anatomy and light acclimation in woody seedlings after gap formation in a cool-temperate deciduous forest. Oecologia 2006, 149, 571-582. [CrossRef] [PubMed]

5. Vazquez-Yanes, C.; Smith, H. Phytochrome control of seed-germination in the tropical rain-forest pioneer trees Cecropia obtusifolia and Piper auritum and its ecological significance. New Phytol. 1982, 92, 477-485. [CrossRef]

6. Way, D.A.; Pearcy, R.W. Sunflecks in trees and forests: From photosynthetic physiology to global change biology. Tree Physiol. 2012, 32, 1066-1081. [CrossRef] [PubMed]

7. Gratani, L. Plant phenotypic plasticity in response to environmental factors. Adv. Bot. 2014, $2014,208747$. [CrossRef]

8. Yang, S.-J.; Sun, M.; Zhang, Y.-J.; Cochard, H.; Cao, K.-F. Strong leaf morphological, anatomical, and physiological responses of a subtropical woody bamboo (Sinarundinaria nitida) to contrasting light environments. Plant Ecol. 2014, 215, 97-109. [CrossRef]

9. Gonçalves, J.F.D.C.; Marenco, R.A.; Vieira, G. Concentration of photosynthetic pigments and chlorophyll fluorescence of mahogany and tonka bean under two light environments. Rev. Bras. Fisiol. Veg. 2001, 13, 149-157. [CrossRef]

10. Castro, J.; Zamora, R.; Hódar, J.A.; Gómez, J.M. Seedling establishment of a boreal tree species (Pinus sylvestris) at its southernmost distribution limit: Consequences of being in a marginal Mediterranean habitat. J. Ecol. 2004, 92, 266-277. [CrossRef]

11. Espelta, J.M.; Riba, M.; Javier, R. Patterns of seedling recruitment in West-Mediterranean Quercus ilex forest influenced by canopy development. J. Veg. Sci. 1995, 6, 465-472. [CrossRef]

12. Gómez-Aparicio, L.; Zamora, R.; Gómez, J.M.; Hódar, J.A.; Castro, J.; Baraza, E. Applying plant facilitation to forest restoration: A meta-analysis of the use of shrubs as nurse plants. Ecol. Appl. 2004, 14, 1128-1138. [CrossRef]

13. Zavala, M.A.; Zea, E. Mechanisms maintaining biodiversity in Mediterranean pine-oak forests: Insights from a spatial simulation model. Plant Ecol. 2004, 171, 197-207. [CrossRef]

14. Valladares, F.; Niinemets, U. Shade tolerance, a key plant feature of complex nature and consequences. Annu. Rev. Ecol. Evol. Syst. 2008, 39, 237-257. [CrossRef]

15. Aleric, K.M.; Katherine Kirkman, L. Growth and photosynthetic responses of the federally endangered shrub, Lindera melissifolia (Lauraceae), to varied light environments. Am. J. Bot. 2005, 92, 682-689. [CrossRef] [PubMed]

16. Demmig-Adams, B.; Adams, W.W. Photoprotection in an ecological context: The remarkable complexity of thermal energy dissipation. New Phytol. 2006, 172, 11-21. [CrossRef] [PubMed]

17. Kageyama, P.Y. Recomposição da Vegetação com Espécies Arbóreas Nativas em Reservatórios de Usinas Hidrelétricas da Cesp; IPEF: Piracicaba, Brazil, 1992. (In Portuguese)

18. Givnish, T.J. Adaptation to sun and shade: A whole-plant perspective. Funct. Plant Biol. 1988, 15, 63-92. [CrossRef]

19. Hanba, Y.T.; Kogami, H.; Terashima, I. The effect of growth irradiance on leaf anatomy and photosynthesis in Acer species differing in light demand. Plant Cell Environ. 2002, 25, 1021-1030. [CrossRef]

20. Walters, R.G. Towards an understanding of photosynthetic acclimation. J. Exp. Bot. 2005, 56, 435-447. [CrossRef] [PubMed]

21. Cano, F.J.; Sánchez-Gómez, D.; Gascó, A.; Rodríguez-Calcerrada, J.; Gil, L.; Warren, C.R.; Aranda, I. Light acclimation at the end of the growing season in two broadleaved oak species. Photosynthetica 2011, 49, 581-592. [CrossRef]

22. Chazdon, R.L.; Pearcy, R.W.; Lee, D.W.; Fetcher, N. Photosynthetic responses of tropical forest plants to contrasting light environments. In Tropical Forest Plant Ecophysiology; Mulkey, S.S., Chazdon, R.L., Smith, A.P., Eds.; Springer: Boston, MA, USA, 1996; pp. 5-55.

23. Niinemets, U.; Sack, L. Structural determinants of leaf light-harvesting capacity and photosynthetic potentials. In Progress in Botany; Esser, K., Lüttge, U., Beyschlag, W., Murata, J., Eds.; Springer: Berlin/Heidelberg, Germany, 2006; pp. 385-419. 
24. Abrams, M.D.; Kubiske, M.E. Leaf structural characteristics of 31 hardwood and conifer tree species in central Wisconsin-Influence of light regime and shade-tolerance rank. For. Ecol. Manag. 1990, 31, 245-253. [CrossRef]

25. Davi, H.; Barbaroux, C.; Dufrene, E.; Francois, C.; Montpied, P.; Brea, N.; Badeck, F. Modelling leaf mass per area in forest canopy as affected by prevailing radiation conditions. Ecol. Model. 2008, 211, 339-349. [CrossRef]

26. Reich, P.B.; Walters, M.B.; Tjoelker, M.G.; Vanderklein, D.; Buschena, C. Photosynthesis and respiration rates depend on leaf and root morphology and nitrogen concentration in nine boreal tree species differing in relative growth rate. Funct. Ecol. 1998, 12, 395-405. [CrossRef]

27. Zhang, L.; Copini, P.; Weemstra, M.; Sterck, F. Functional ratios among leaf, xylem and phloem areas in branches change with shade tolerance, but not with local light conditions, across temperate tree species. New Phytol. 2016, 209, 1566-1575. [CrossRef] [PubMed]

28. Hoffmann, W.A.; Franco, A.C. Comparative growth analysis of tropical forest and savanna woody plants using phylogenetically independent contrasts. J. Ecol. 2003, 91, 475-484. [CrossRef]

29. Moreira, A.; Queiroz, A.C.L.; Barros, F.D.; Goulart, M.F.; Lemos-Filho, J.P. Do leaf traits in two Dalbergia species present differential plasticity in relation to light according to their habitat of origin? Aust. J. Bot. 2013, 61, 592-599. [CrossRef]

30. Lee, D.W.; Baskaran, K.; Mansor, M.; Mohamad, H.; Yap, S.K. Irradiance and spectral quality affect Asian tropical rain forest tree seedling development. Ecology 1996, 77, 568-580. [CrossRef]

31. Smith, H. Light quality, photoperception, and plant strategy. Annu. Rev. Plant Physiol. 1982, 33, 481-518. [CrossRef]

32. Casal, J.J.; Sánchez, R.A. Phytochromes and seed germination. Seed Sci. Res. 1998, 8, 317-329. [CrossRef]

33. Smith, H. Sensing the light environment: The functions of the phytochrome family. In Photomorphogenesis in Plants; Kendrick, R.E., Kronenberg, G.H.M., Eds.; Springer: Dordrecht, The Netherlands, 1994; pp. 377-416.

34. Taiz, L.; Zeiger, E. Plant Physiology, 4th ed.; Sinauer Associates, Inc.: Sunderland, MA, USA, 2006; p. 764.

35. Ballaré, C.L.; Casal, J.J. Light signals perceived by crop and weed plants. Field Crops Res. 2000, 67, 149-160. [CrossRef]

36. Franklin, K.A.; Whitelam, G.C. Phytochromes and shade-avoidance responses in plants. Ann. Bot. 2005, 96, 169-175. [CrossRef] [PubMed]

37. Gautier, H.; Měch, R.; Prusinkiewicz, P.; Varlet-Grancher, C. 3D architectural modelling of aerial photomorphogenesis in white clover (Trifolium repens L.) using L-systems. Ann. Bot. 2000, 85, 359-370. [CrossRef]

38. Héraut-Bron, V.; Robin, C.; Varlet-Grancher, C.; Guckert, A. Phytochrome mediated effects on leaves of white clover: Consequences for light interception by the plant under competition for light. Ann. Bot. 2001, 88 (Suppl. 1), 737-743. [CrossRef]

39. Li, J.; Li, G.; Wang, H.; Wang Deng, X. Phytochrome signaling mechanisms. Arabidopsis Book 2011, 9. [CrossRef] [PubMed]

40. Lima, R.S.D.; Oliveira, P.L.D.; Rodrigues, L.R. Anatomia do lenho de Enterolobium contortisiliquum (Vell.) Morong (Leguminosae-Mimosoideae) ocorrente em dois ambientes. Braz. J. Bot. 2009, 32, 361-374. (In Portuguese) [CrossRef]

41. Prado, D.E.; Gibbs, P.E. Patterns of species distributions in the dry seasonal forests of South America. Ann. Mo. Bot. Gard. 1993, 902-927. [CrossRef]

42. USDA. The Plants Database. Available online: http://plants.usda.gov (accessed on 28 November 2016).

43. Lopes, G.L. Compêndio Online Gerson Luiz Lopes: Laboratório de Manejo Florestal. Available online: http:/ / sites.unicentro.br/wp/manejoflorestal/6668-2/ (accessed on 15 March 2016). (In Portuguese)

44. Recomendações de Adubação para Eucalyptus, Pinus e Espécies Nativas. Available online: http://www. ipef.br/silvicultura/adubacao.asp (accessed on 5 July 2013). (In Portuguese)

45. Kanegae, M.F.; Braz, V.D.S.; Franco, A.C. Efeitos da seca sazonal e disponibilidade de luz na sobrevivência e crescimento de Bowdichia virgilioides em duas fitofisionomias típicas dos cerrados do Brasil Central. Braz. J. Bot. 2000, 23, 459-468. (In Portuguese) [CrossRef]

46. Arnon, D.I. Copper enzymes in isolated chloroplasts. Polyphenoloxidase in Beta vulgaris. Plant Physiol. 1949, 24, 1-15. [CrossRef] [PubMed] 
47. Lichtenthaler, H.K.; Buschmann, C. Chlorophylls and carotenoids: Measurement and characterization by UV-VIS spectroscopy. In Current Protocols in Food Analytical Chemistry; John Wiley \& Sons, Inc.: Hoboken, NJ, USA, 2001.

48. Silva, F.C. Análise Química de Tecido Vegetal. In Manual de Análises Químicas de Solo, Plantas e Fertilizantes; Embrapa Informação Tecnológica: Brasília, Brazil, 2009. (In Portuguese)

49. Johansen, D.A. Plant Microtechnique; McGraw-Hill Book Company, Inc.: London, UK, 1940.

50. Obrien, T.P.; Feder, N.; McCully, M.E. Polychromatic staining of plant cell walls by toluidine blue O. Protoplasma 1964, 59, 368-373. [CrossRef]

51. Souza, J.P.; Melo, N.M.J.; Halfed, A.D.; Reis, J.N. Shading effects on leaf life span and functional traits in the widespread species Enterolobium contortisiliquum (Vell.) Morong. Acta Sci. Biol. Sci. 2017, 39, 113-122. [CrossRef]

52. Boardman, N.K. Comparative photosynthesis of sun and shade plants. Annu. Rev. Plant Physiol. 1977, 28, 355-377. [CrossRef]

53. Rossatto, D.R.; Takahashi, F.S.C.; Silva, L.D.C.R.; Franco, A.C. Características funcionais de folhas de sol e sombra de espécies arbóreas em uma mata de galeria no Distrito Federal, Brasil. Acta Bot. Bras. 2010, 24, 640-647. (In Portuguese) [CrossRef]

54. Li, X.F.; Schmid, B.; Wang, F.; Paine, C.E.T. Net assimilation rate determines the growth rates of 14 species of subtropical forest trees. PLoS ONE 2016, 11, e0150644. [CrossRef] [PubMed]

55. Lima, A.L.D.S.; Zanella, F.; Castro, L.D.M.D. Crescimento de Hymenaea courbaril L. var. stilbocarpa (Hayne) Lee et Lang. e Enterolobium contortisiliquum (Vell.) Morong (Leguminosae) sob diferentes níveis de sombreamento. Acta Amazon. 2010, 40, 43-48. (In Portuguese) [CrossRef]

56. Markesteijn, L.; Poorter, L.; Bongers, F. Light-dependent leaf trait variation in 43 tropical dry forest tree species. Am. J. Bot. 2007, 94, 515-525. [CrossRef] [PubMed]

57. Walters, M.B.; Reich, P.B. Low-light carbon balance and shade tolerance in the seedlings of woody plants: Do winter deciduous and broad-leaved evergreen species differ? New Phytol. 1999, 143, 143-154. [CrossRef]

58. Melo, R.R.; CL Cunha, M.D.; Júnior, F.R.; Stangerlin, D.M. Crescimento inicial de mudas de Enterolobium contortisiliquum (Vell.) Morong. sob diferentes níveis de luminosidade. Rev. Bras. Ciênc. Agrárias 2008, 3, 138-144. (In Portuguese) [CrossRef]

59. Kitajima, K. Relative importance of photosynthetic traits and allocation patterns as correlates of seedling shade tolerance of 13 tropical trees. Oecologia 1994, 98, 419-428. [CrossRef] [PubMed]

60. Gilbert, I.R.; Jarvis, P.G.; Smith, H. Proximity signal and shade avoidance differences between early and late successional trees. Nature 2001, 411, 792-795. [CrossRef] [PubMed]

61. Naves, V.L.; Alvarenga, A.A.; Oliveira, L.E.M. Comportamento estomático de mudas de três espécies florestais submetidas a diferentes níveis de radiação fotossinteticamente ativa. Ciênc. Prát. 1994, 18, 408-414. (In Portuguese)

62. Capuzzo, J.P.; Rossatto, D.R.; Franco, A.C. Differences in morphological and physiological leaf characteristics between Tabebuia aurea and T. impetiginosa is related to their typical habitats of occurrence. Acta Bot. Bras. 2012, 26, 519-526. [CrossRef]

63. Gonçalves, E.R.; Souza, F.C.; Santos, L.N.D.; Silva, J.V.; Ferreira, V.M.; Endres, L. Morphological and photosynthetic adaptations of Tabebuia aurea seedlings in the nursery. Rev. Bras. Eng. Agríc. Ambient. 2013, 17, 1201-1209. [CrossRef]

64. Ivancich, H.S.; Lencinas, M.V.; Pastur, G.J.M.; Esteban, R.M.S.; Hernández, L.; Lindstrom, I. Foliar anatomical and morphological variation in Nothofagus pumilio seedlings under controlled irradiance and soil moisture levels. Tree Physiol. 2012, 32, 554-564. [CrossRef] [PubMed]

65. Smith, W.K. Temperatures of desert plants: Another perspective on the adaptability of leaf size. Science 1978, 201, 614-616. [CrossRef] [PubMed]

66. Abrams, M.D.; Mostoller, S.A. Gas-exchange, leaf structure and nitrogen in contrasting successional tree species growing in open and understory sites during a drought. Tree Physiol. 1995, 15, 361-370. [CrossRef] [PubMed]

67. Drake, P.L.; Froend, R.H.; Franks, P.J. Smaller, faster stomata: Scaling of stomatal size, rate of response, and stomatal conductance. J. Exp. Bot. 2013, 64, 495-505. [CrossRef] [PubMed]

68. Niinemets, U.; Valladares, F. Tolerance to shade, drought, and waterlogging of temperate Northern Hemisphere trees and shrubs. Ecol. Monogr. 2006, 76, 521-547. [CrossRef] 
69. Huang, D.; Wu, L.; Chen, J.R.; Dong, L. Morphological plasticity, photosynthesis and chlorophyll fluorescence of Athyrium pachyphlebium at different shade levels. Photosynthetica 2011, 49, 611-618. [CrossRef]

70. Zhang, S.-B.; Hu, H.; Xu, K.; Li, Z.-R.; Yang, Y.-P. Flexible and reversible responses to different irradiance levels during photosynthetic acclimation of Cypripedium guttatum. J. Plant Physiol. 2007, 164, 611-620. [CrossRef] [PubMed]

71. Casal, J.J.; Aphalo, P.J.; Sanchez, R.A. Phytochrome effects on leaf growth and chlorophyll content in Petunia axilaris. Plant Cell Environ. 1987, 10, 509-514. [CrossRef]

72. Souza, S.D.C.R.; Santos, V.A.H.; Ferreira, M.J.; Gonçalves, J.F. Biomassa, crescimento e respostas ecofisiológicas de plantas jovens de Bertholletia excelsa bonpl. submetidas a diferentes níveis de irradiância. Ciênc. Florest. 2017, 27, 557-569. (In Portuguese) [CrossRef]

73. Matsubara, S.; Krause, G.H.; Aranda, J.; Virgo, A.; Beisel, K.G.; Jahns, P.; Winter, K. Sun-shade patterns of leaf carotenoid composition in 86 species of neotropical forest plants. Funct. Plant Biol. 2009, 36, 20-36. [CrossRef]

74. Demmig-Adams, B.; Adams Iii, W.W. Photoprotection and other responses of plants to high light stress. Annu. Rev. Plant Physiol. Plant Mol. Biol. 1992, 43, 599-626. [CrossRef]

75. Lacerda, D.M.A.; Figueiredo, P.S.D. Restauração de matas ciliares do rio Mearim no município de Barra do Corda-MA: Seleção de espécies e comparação de metodologias de reflorestamento. Acta Amazon. 2009, 39, 295-304. (In Portuguese) [CrossRef]

76. Telfer, A. What is beta-carotene doing in the photosystem II reaction center? Philos. Trans. R. Soc. Lond. Ser. B-Biol. Sci. 2002, 357, 1431-1439. [CrossRef] [PubMed]

77. Weston, E.; Thorogood, K.; Vinti, G.; López-Juez, E. Light quantity controls leaf-cell and chloroplast development in Arabidopsis thaliana wild type and blue-light-perception mutants. Planta 2000, 211, 807-815. [CrossRef] [PubMed]

78. Poorter, L. Growth responses of 15 rain-forest tree species to a light gradient: The relative importance of morphological and physiological traits. Funct. Ecol. 1999, 13, 396-410. [CrossRef]

79. Anderson, J.M.; Chow, W.S.; Park, Y.I. The grand design of photosynthesis: Acclimation of the photosynthetic apparatus to environmental cues. Photosynth Res. 1995, 46, 129-139. [CrossRef] [PubMed]

80. Gommers, C.M.M.; Visser, E.J.W.; St Onge, K.R.; Voesenek, L.; Pierik, R. Shade tolerance: When growing tall is not an option. Trends Plant Sci. 2013, 18, 65-71. [CrossRef] [PubMed]

81. Ballaré, C.L.; Scopel, A.L.; Sanchez, R.A. On the opportunity cost of the photosynthate invested in stem elongation reactions mediated by phytochrome. Oecologia 1991, 86, 561-567. [CrossRef] [PubMed]

82. Moraes Neto, S.; Gonçalves, J.D.M.; Takaki, M.; Cenci, S.; Gonçalves, J. Crescimento de mudas de algumas espécies arbóreas que ocorrem na mata atlântica, em função do nível de luminosidade. Rev. Árv. 2000, 24, 35-45. (In Portuguese)

83. Ballaré, C.L. Keeping up with the neighbors: Phytochrome sensing and other signaling mechanisms. Trends Plant Sci. 1999, 4, 97-102. [CrossRef]

84. Parks, B.M.; Folta, K.M.; Spalding, E.P. Photocontrol of stem growth. Curr. Opin. Plant Biol. 2001, 4, 436-440. [CrossRef]

85. Lessa, B.F.D.T.; de Almeida, J.P.N.; Pinheiro, C.L.; Gomes, F.M.; Medeiros-Filho, S. Germination and seedling growth of Enterolobium contortisiliquum as a function of seed weight and temperature and light conditions. Agrociencia 2015, 49, 315-327.

86. Poorter, L. Leaf traits show different relationships with shade tolerance in moist versus dry tropical forests. New Phytol. 2009, 181, 890-900. [CrossRef] [PubMed]

87. Tong, P.S.; Ng, F.S.P. Effect of light intensity on growth, leaf production, leaf lifespan and leaf nutrient budgets of Acacia mangium, Cinnamomum iners, Dyera costulata, Eusideroxylon zwageri and Shorea roxburghii. J. Trop. For. Sci. 2008, 20, 218-234.

88. Kikuzawa, K. A cost-benefit analysis of leaf habit and leaf longevity of trees and their geographical pattern. Am. Nat. 1991, 138, 1250-1263. [CrossRef]

89. Kikuzawa, K. Geographical distribution of leaf life span and species diversity of trees simulated by a leaf-longevity model. Vegetatio 1996, 122, 61-67. [CrossRef]

90. Reich, P.B.; Walters, M.B.; Ellsworth, D.S. Leaf life-span in relation to leaf, plant, and stand characteristics among diverse ecosystems. Ecol. Monogr. 1992, 62, 365-392. [CrossRef] 
91. Kikuzawa, K.; Lechowicz, M.J. Theories of leaf longevity. In Ecology of Leaf Longevity; Springer: Tokyo, Japan, 2011; pp. 41-56.

92. Lemos-Filho, J.; Barros, C.; Dantas, G.; Dias, L.; Mendes, R. Spatial and temporal variability of canopy cover and understory light in a Cerrado of Southern Brazil. Braz. J. Biol. 2010, 70, 19-24. [CrossRef] [PubMed]

93. Kikuzawa, K. Leaf survival of woody-plants in deciduous broad-leaved forests.1. Tall trees. Can. J. Bot. Rev. Can. Bot. 1983, 61, 2133-2139. [CrossRef]

94. Janse-ten Klooster, S.H.; Thomas, E.J.P.; Sterck, F.J. Explaining interspecific differences in sapling growth and shade tolerance in temperate forests. J. Ecol. 2007, 95, 1250-1260. [CrossRef]

95. Lusk, C.H.; Warton, D.I. Global meta-analysis shows that relationships of leaf mass per area with species shade tolerance depend on leaf habit and ontogeny. New Phytol. 2007, 176, 764-774. [CrossRef] [PubMed]

96. Dickson, A.; Leaf, A.L.; Hosner, J.F. Quality appraisal of white spruce and white pine seedling stock in nurseries. For. Chron. 1960, 36, 10-13. [CrossRef]

97. Ritchie, G.A. Assessing seedling quality. In Forestry Nursery Manual: Production of Bareroot Seedlings; Duryea, M.L., Landis, T.D., Perry, C.R., Eds.; Springer: Dordrecht, The Netherlands, 1984; pp. 243-259.

98. Claussen, J.W. Acclimation abilities of three tropical rainforest seedlings to Eincrease in light intensity. For. Ecol. Manag. 1996, 80, 245-255. [CrossRef]

(c) 2018 by the authors. Licensee MDPI, Basel, Switzerland. This article is an open access article distributed under the terms and conditions of the Creative Commons Attribution (CC BY) license (http://creativecommons.org/licenses/by/4.0/). 